\title{
Long-term changes in lower tropospheric baseline ozone concentrations at northern mid-latitudes
}

\author{
D. D. Parrish ${ }^{1}$, K. S. Law ${ }^{2}$, J. Staehelin ${ }^{3}$, R. Derwent ${ }^{4}$, O. R. Cooper ${ }^{5,1}$, H. Tanimoto ${ }^{6}$, A. Volz-Thomas ${ }^{7}$, S. Gilge ${ }^{8}$, \\ H.-E. Scheel ${ }^{9}$, M. Steinbacher ${ }^{10}$, and E. Chan ${ }^{11}$ \\ ${ }^{1}$ NOAA ESRL Chemical Sciences Division, 325 Broadway, Boulder, CO, USA \\ ${ }^{2}$ UPMC Univ. Paris 06, Univ. Versailles Saint-Quentin, CNRS/INSU, UMR8190, LATMOS/IPSL, Paris, France \\ ${ }^{3}$ Institute for Atmospheric and Climate Science, ETHZ, Universitätstrasse 16, 8092 Zürich, Switzerland \\ ${ }^{4}$ rdscientific, Newbury, Berkshire RG14 6LH, UK \\ ${ }^{5}$ CIRES, University of Colorado, Boulder, CO, USA \\ ${ }^{6}$ National Institute for Environmental Studies, 16-2 Onogawa, Tsukuba, Ibaraki 305-8506, Japan \\ ${ }^{7}$ IEK-8, Forschungszentrum Juelich, 52425 Juelich, Germany \\ ${ }^{8}$ Hohenpeissenberg Meteorological Observatory, German Meteorological Service (DWD), Hohenpeissenberg, Germany \\ ${ }^{9}$ Karlsruhe Institute of Technology, IMK-IFU, 82467 Garmisch-Partenkirchen, Germany \\ ${ }^{10}$ Swiss Federal Laboratories for Materials Science and Technology (EMPA), Duebendorf, Switzerland \\ ${ }^{11}$ Science and Technology Branch, Environment Canada, 4905 Dufferin Street, Toronto, Ontario, Canada \\ Correspondence to: D. D. Parrish (david.d.parrish@noaa.gov)
}

Received: 10 April 2012 - Published in Atmos. Chem. Phys. Discuss.: 5 June 2012

Revised: 6 November 2012 - Accepted: 16 November 2012 - Published: 4 December 2012

\begin{abstract}
Changes in baseline (here understood as representative of continental to hemispheric scales) tropospheric $\mathrm{O}_{3}$ concentrations that have occurred at northern mid-latitudes over the past six decades are quantified from available measurement records with the goal of providing benchmarks to which retrospective model calculations of the global $\mathrm{O}_{3}$ distribution can be compared. Eleven data sets (ten groundbased and one airborne) including six European (beginning in the 1950's and before), three North American (beginning in 1984) and two Asian (beginning in 1991) are analyzed. When the full time periods of the data records are considered a consistent picture emerges; $\mathrm{O}_{3}$ has increased at all sites in all seasons at approximately $1 \% \mathrm{yr}^{-1}$ relative to the site's 2000 yr mixing ratio in each season. For perspective, this rate of increase sustained from 1950 to 2000 corresponds to an approximate doubling. There is little if any evidence for statistically significant differences in average rates of increase among the sites, regardless of varying length of data records. At most sites (most definitively at the European sites) the rate of increase has slowed over the last decade (possibly longer), to the extent that at present $\mathrm{O}_{3}$ is decreasing at some sites in some seasons, particularly in summer.
\end{abstract}

The average rate of increase before 2000 shows significant seasonal differences $(1.08 \pm 0.09,0.89 \pm 0.10,0.85 \pm 0.11$ and $1.21 \pm 0.12 \% \mathrm{yr}^{-1}$ in spring, summer, autumn and winter, respectively, over North America and Europe).

\section{Introduction and background}

Tropospheric ozone $\left(\mathrm{O}_{3}\right)$, and its changes over time, attract much scientific attention because $\mathrm{O}_{3}$ is a strong greenhouse gas and the significant tropospheric $\mathrm{O}_{3}$ increases that occurred during the last century have contributed to changes in radiative forcing and therefore to climate change (IPCC, 2007). Ozone is also an important air pollutant that at high concentrations damages human health and ecosystems including crops; as such it is often utilized as a tracer for anthropogenic influences in atmospheric measurements (for more information see Royal Society, 2008). Tropospheric $\mathrm{O}_{3}$ has a significant natural source from $\mathrm{O}_{3}$ produced in the stratosphere and transported downwards by the largescale Brewer-Dobson circulation, primarily at mid-latitudes (e.g., Junge, 1963; Collins et al., 2003). It is destroyed by 


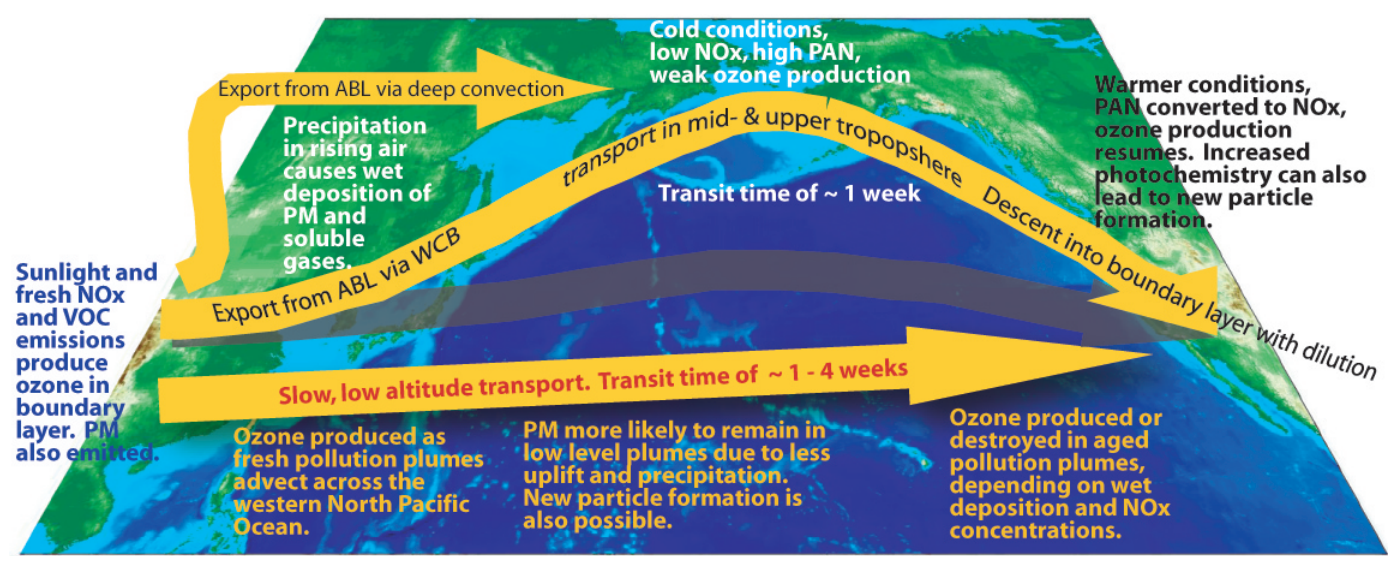

Fig. 1. General intercontinental transport processes. Blue text on the left applies to continental boundary layer processes, yellow/red text apples to low-level transport and black/white text applies to high-altitude transport (based upon HTAP, 2010; original figure courtesy of O. Cooper).

dry deposition at the surface (e.g., Galbally and Roy, 1980). In addition, since the 1970s, it has been known that $\mathrm{O}_{3}$ has significant photochemical sources and sinks. Under polluted conditions, it is largely depleted through reaction with nitric oxide (NO) emitted from combustion processes. At lower nitrogen oxide $\left(\mathrm{NO}_{\mathrm{x}}=\mathrm{NO}+\mathrm{NO}_{2}\right)$ concentrations, $\mathrm{O}_{3}$ is produced via reactions involving oxidation of methane $\left(\mathrm{CH}_{4}\right)$, carbon monoxide $(\mathrm{CO})$ and volatile organic compounds (VOCs) in the presence of sunlight and $\mathrm{NO}_{\mathrm{x}}$ leading to the formation of high concentrations of $\mathrm{O}_{3}$ and other photochemical oxidants including peroxyacetyl nitrate (PAN) (Chameides and Walker, 1973; Crutzen, 1973). $\mathrm{O}_{3}$ is also destroyed via reactions involving water vapor and $\mathrm{O}_{3}$ photolysis leading to the production of the hydroxyl radical, the primary tropospheric oxidant for $\mathrm{CH}_{4}, \mathrm{CO}$ and VOCs. Thus, the concentration of $\mathrm{O}_{3}$ in the troposphere has a complex dependence on concentrations of its precursors and water vapor (Ayers et al., 1992). These precursor gases have both natural and anthropogenic sources which vary on diurnal, seasonal and inter-annual timescales.

Tropospheric $\mathrm{O}_{3}$ has a lifetime with respect to photochemical loss that varies between a few to 20-30 days or longer depending on season and altitude with longer lifetimes in the upper troposphere (Fusco and Logan, 2003). In the lower troposphere its lifetime is shorter in the summer (around 5 days) due to higher water vapor concentrations. Dry deposition diminishes the lifetime of $\mathrm{O}_{3}$ within the planetary boundary layer over continental areas. Given its long lifetime relative to transport timescales at, for example, northern mid-latitudes, $\mathrm{O}_{3}$ can be transported away from source regions from one continent to another (e.g. Guerova et al., 2006). Following early studies by Chameides and Walker $(1973,1976)$ and Cox et al. (1975), this has led to the recognition that $\mathrm{O}_{3}$ is not only a pollutant at local/regional scales near major emission regions, but also it is a pollutant on hemispheric scales where it can contribute to so-called background levels as dis- cussed in detail in the recent Hemispheric Transport of Air Pollutants (HTAP) report (HTAP, 2010). Early analysis of clean "background" air masses, showing spring maxima in $\mathrm{O}_{3}$ and PAN, supported the hypothesis that $\mathrm{O}_{3}$ is produced photochemically rather than just being transported from the stratosphere (Penkett and Brice, 1986). Since then, it has become apparent that PAN plays an important role in the intercontinental budget of $\mathrm{O}_{3}$ since it can also be transported over long distances between continents in the cold upper troposphere, where it is stable, before descending and releasing $\mathrm{NO}_{\mathrm{x}}$ due to thermal decomposition resulting in important secondary production of $\mathrm{O}_{3}$ over downwind regions (e.g. Wild et al., 1996). This process and others influencing $\mathrm{O}_{3}$ during long-range transport are summarized in Fig. 1 (HTAP, 2010).

During the latter half of the 20th century $\mathrm{O}_{3}$ concentrations increased markedly at northern mid-latitudes. This increase has been documented by a variety of observational studies (see reviews by Vingarzan, 2004; Oltmans et al., 2006 and references therein), and is generally attributed to increasing anthropogenic emissions that accompanied economic growth of industrialized nations (e.g., Horowitz, 2006; Lamarque et al., 2005) and fueled photochemical $\mathrm{O}_{3}$ production. This observed increase is one of the most important manifestations of the hemispheric transport of air pollution. Variability in stratospheric flux may have also played a role in increases in recent years (e.g Ordóñez et al., 2007; Hess and Zbinden, 2011) although other studies do not find a large stratospheric influence, at least in the mid to lower troposphere (Cooper et al., 2010; Cui et al., 2011). Changing transport patterns may also be important such as changes in the North Atlantic Oscillation influence over Europe (Pausata et al., 2012). Uncertainty remains regarding the magnitude of the increase from pre-industrial to present day since preindustrial $\mathrm{O}_{3}$ concentrations are poorly known with few measurements made before the late 1970s, and different data sets 
for the same region not always giving consistent results. Nevertheless, it does appear that concentrations were lower up to the 1950s with mixing ratios (strictly speaking mole fractions) around 10-20 ppbv, for example, over Europe (Volz and Kley, 1988; Staehelin et al., 1994).

Changing concentrations in hemispheric $\mathrm{O}_{3}$ have implications for regional air quality where $\mathrm{O}_{3}$ imported into a downwind receptor region can contribute to observed $\mathrm{O}_{3}$ and local air quality degradation. Over certain regions in the Northern Hemisphere, such as Europe and North America, ambient $\mathrm{O}_{3}$ standards established from an air quality perspective have been decreased due to human health and ecological considerations to the point that $\mathrm{O}_{3}$ concentrations in even remote areas of the northern mid-latitudes can approach or even exceed these standards. Thus, regional to hemispheric scale transport must be considered when dealing with local air quality concerns, for example, as part of the Convention on the Long-Range Transport of Air Pollutants (CLRTAP) (HTAP, 2010).

The major regions of anthropogenic emissions of $\mathrm{O}_{3}$ precursors are at northern mid-latitudes: Europe, North America and more recently East Asia. While emissions have increased substantially overall since the $1950 \mathrm{~s}$, certain regions have implemented emissions controls since the 1980s leading to decreases in $\mathrm{O}_{3}$ precursor emissions (Lamarque et al., 2010; Granier et al., 2011). For example, $\mathrm{NO}_{\mathrm{x}}$ emissions are estimated to have declined by $30 \%$ over Europe (1990-2005) and $37 \%$ over the United States (1985-2008; Granier et al., 2011). In contrast, emissions over Asia have increased with, for example, $\mathrm{NO}_{\mathrm{x}}$ emissions over eastern Asia increasing by $7 \%$ per year between 2001 and 2006 (Ohara et al., 2007).

The major pathways for intercontinental transport of pollutants are above the planetary boundary layer (PBL) (see Fig. 1, and e.g., Forster et al., 2004); since the lifetime of $\mathrm{O}_{3}$ above the PBL is long with respect to the time required for intercontinental transport, we expect regional changes in $\mathrm{O}_{3}$ sources to result in concentration changes that are propagated zonally through this transport. Thus, we also expect long-term $\mathrm{O}_{3}$ changes to be similar through all longitudes at northern mid-latitudes, but the multiple records of $\mathrm{O}_{3}$ measurements have not been fully analyzed from this perspective. Some past analyses have shown some similarity in $\mathrm{O}_{3}$ changes at northern mid-latitudes:

- Ozone doubled in the Swiss Alps from the 1950s to the early 1990s (Staehelin et al., 1994) and a similar increase was noted at Arkona on the German Baltic coast (Feister and Warmbt, 1987).

- Sonde data show $\mathrm{O}_{3}$ increased over Europe from the 1970 s to the 1990s, although the details of the increase differ among the three long-term ozone sonde stations (Logan, 1994; Logan et al., 1999).
- Ozone at Mace Head on the west coast of Ireland increased from 1987 to the late 1990s with no significant increase thereafter (Derwent et al., 2007).

- Alpine sites in Europe show $\mathrm{O}_{3}$ increased from 1978 until around 2000 and then stabilized (Logan et al., 2012 and references cited therein).

- A synthesis of sonde, MOZAIC, and alpine site data from central Europe (Logan et al., 2012) suggests that ozone has decreased since 1998, with the largest decrease in summer.

- Ozone was also found to have increased on the west coast of the US (Jaffe et al., 2003; Parrish et al., 2009; Cooper et al., 2010).

- Large $\mathrm{O}_{3}$ increases have been reported in spring at Mt. Happo, the only mountain site in Japan (Tanimoto et al., 2009).

Our primary goal in this paper is to investigate the hypothesis that $\mathrm{O}_{3}$ has increased at statistically similar rates over the last half of the twentieth century throughout northern midlatitudes. We concentrate primarily on analysis of groundbased $\mathrm{O}_{3}$ measurements from relatively remote surface and mountain top sites (maps of the sites are given in Fig. S20 of the Supplement) and also include one study based on MOZAIC commercial aircraft data, airborne research campaigns, sonde and lidar data (Cooper et al., 2010). Other types of measurements, such as ozone sonde or lidar records, are generally not considered. It is desired to obtain a quantitative description of long-term changes in lower tropospheric $\mathrm{O}_{3}$ concentrations at northern mid-latitudes over the longest possible time scales. To the fullest extent possible we aim to examine baseline $\mathrm{O}_{3}$ concentrations (defined below), but it must be recognized that all surface measurements are affected to some degree by more local effects. Where possible, we compare the results of our analysis with earlier publications within the respective sections of the discussion. We include more recent data (through 2010 where possible) and analyze all data sets with consistent procedures designed to provide a robust quantitative analysis that allows comparison of diverse time series of data. The results test the above hypothesis and serve as benchmarks to which retrospective model calculations can be compared. This paper expands the discussion of long-term Northern Hemisphere $\mathrm{O}_{3}$ changes included in HTAP (2010); it presents more detailed descriptions and analyses of the data and includes more recent data.

This paper is organized as follows. Section 2 deals with several important issues that must be considered when analyzing $\mathrm{O}_{3}$ changes with the aim of determining the contribution that hemispheric transport makes to $\mathrm{O}_{3}$ over downwind receptor regions. Section 3 describes the data sets and Sect. 4 presents the analysis methodology and results at different locations in the Northern Hemisphere. A discussion 
and comparison with other studies is provided in Sect. 5 with conclusions in Sect. 6.

\section{Issues related to quantifying ozone changes}

\subsection{Multiple influences on local ozone concentrations}

Regional air quality over populated areas is influenced by surface $\mathrm{O}_{3}$ concentrations that may have a varying mix of local, regional and long-distance origins. The contribution from $\mathrm{O}_{3}$ imported from outside a region varies as a function of location and time of year and depends on many factors including transport patterns influencing a particular site and proximity to local emissions. Thus, long-term $\mathrm{O}_{3}$ measurements collected within or near major emission regions reflect changes in both local, regional and distant precursor emissions as well as inter-annual variability in transport processes and natural sources (e.g. input from the stratosphere and photochemical production from natural $\mathrm{O}_{3}$ precursors).

Since all locations in the Northern Hemisphere are impacted to a greater or lesser degree by anthropogenic $\mathrm{O}_{3} \mathrm{im}$ ported from upwind regions, it is impossible to determine from measurements alone so-called natural background concentrations with no human influence. In reality, observations at even relatively isolated measurement sites reveal a spectrum of concentrations in aged and well-mixed air masses with a range of origins. Sporadic episodes, often identified by signatures of enhanced pollutant tracers such as $\mathrm{CO}$, are superimposed on this spectrum. Some locations receive large fractions of imported air masses and are thus much less affected by recent (i.e. within the last few days) local and regional influences. Such sites are found on the west coasts of North America or Europe and sites at higher altitudes in the continental interiors. These sites have typically been used to examine changes in hemispheric $\mathrm{O}_{3}$ concentrations; they are the focus of this study.

\subsection{Baseline versus background ozone concentrations}

From a policy perspective, it is important to diagnose the amount of $\mathrm{O}_{3}$ imported into a region and how that amount has changed over long time periods, since the effectiveness of local emission controls can only be judged if this quantity is known. This $\mathrm{O}_{3}$ has often been referred to as "background" $\mathrm{O}_{3}$, although this term is misleading since all locations in the Northern Hemisphere are influenced by longrange transport of pollution. A more useful concept adopted in this paper and discussed further below is "baseline" $\mathrm{O}_{3}$, which is derived from measurements at times when local emission influences are determined to be negligible. In the United States a somewhat related concept is the policy relevant background (PRB), which must be derived from model calculated $\mathrm{O}_{3}$ concentrations with all North American anthropogenic emissions switched off (e.g. Zhang et al., 2011); McDonald-Buller et al. (2011) present a recent review. In
HTAP (2010) global models were also used to define relative annual intercontinental responses (RAIRs) based on the ratio of simulated surface $\mathrm{O}_{3}$ changes in a receptor region due to $20 \%$ reductions in anthropogenic emissions in individual upwind regions compared to changes due to $20 \%$ reductions in all emission regions including the receptor region. These results showed that between 32 and $43 \%$ of predicted surface $\mathrm{O}_{3}$ changes are due to non-local emissions confirming the importance of inter-continental transport for tropospheric $\mathrm{O}_{3}$. The following discussion in this paper will address "baseline" $\mathrm{O}_{3}$, and its long-term changes.

Ideally, long-term changes in $\mathrm{O}_{3}$ that are representative of continental to hemispheric scales would be routinely diagnosed using baseline $\mathrm{O}_{3}$ observations from a network of relatively remote measurement sites. These baseline $\mathrm{O}_{3}$ concentrations can be obtained from measurement records by removing data collected when sampled air masses are affected by local influences. However, in practice determination of such baseline concentrations is difficult, since meteorological conditions and proximity to local sources vary significantly from site to site. When baseline data selection has not been accomplished, the entire measurement record from sites and platforms believed to primarily represent regional and inter-continental scale $\mathrm{O}_{3}$ concentrations (e.g. mountain top sites, MOZAIC and other aircraft data) have been analyzed to diagnose long-term $\mathrm{O}_{3}$ concentration changes. In the primary analysis presented in this paper, three data sets with baseline selection and eight data sets without such selection are analyzed. Where possible, comparisons of long-term $\mathrm{O}_{3}$ changes determined with and without baseline selection are discussed. This comparison and the consistency in the derived $\mathrm{O}_{3}$ changes over large regions support the assumption that the derived changes from all eleven data sets are representative of long-term changes in baseline $\mathrm{O}_{3}$ concentrations. Nevertheless, a contribution from regional $\mathrm{O}_{3}$ sources remains in these data sets. Global models are often compared to total data sets, but comparison with baseline-selected data is also useful for evaluation of simulated trends since it allows the separation between remote and local/regional emission influences on hemispheric $\mathrm{O}_{3}$.

\section{Data sets}

The goal of this paper has two aspects: first, to accurately quantify the changes in tropospheric $\mathrm{O}_{3}$ concentrations that have occurred at northern mid-latitudes over the full time periods covered by well-characterized measurements, and second, to focus upon changes that are characteristic of regional to hemisphere scales, i.e. baseline $\mathrm{O}_{3}$ concentrations, and to isolate them from more local influences. The data sets selected for analysis represent the longest, highest quality measurement records available from sites that approximate baseline conditions. Unless otherwise noted all data from all times of day are included in the analysis. $\mathrm{O}_{3}$ measurements 
obtained by the method of "Schönbein papers" are not considered in this study because their data quality has been questioned (Kley et al., 1988) The $\mathrm{O}_{3}$ series collected at the $\mathrm{Ob}$ servatoire de Montsouris between 1887 and 1911, although obtained with a quantitative method (c.f., Volz and Kley, 1988), was excluded because of the geographical location of the observatory in the outskirts of Paris with potentially much larger influences of dry deposition on the measured $\mathrm{O}_{3}$ concentrations than at the remote sites considered in our study. The earliest measurements that allow some comparison for consistency (see Staehelin et al., 1994) are available from Europe near the middle of the 20th century, so a characterization over the last six decades is possible. To achieve these goals, a limited number of data sets have been selected for analysis based upon three criteria: (1) the length of the measurement record, (2) the regional representativeness of the measurement site, and (3) at least some coverage of all three northern mid-latitude continents. In particular, for Europe and North America sites were selected that receive a significant fraction of air masses from an upwind westerly direction. Given the lack of long-term data over Asia in regions upwind of Asian emissions, and the fact that its geographical situation makes it difficult to identify signatures of pollutant import, we have chosen to include sites directly downwind from the Asian continent. A total of eleven data sets (Table 1) were selected: six European, three North American and two Asian. Maps showing the locations of the sites where these data were collected are given in Fig. S20 of the Supplement. Complementary analysis of two additional sites downwind of North America is included. Unless noted otherwise, modern UV absorption instruments were utilized for all of the measurements. The analysis presented here is based upon archived data sets. The references given in Table 1 summarize important aspects of these data sets and the measurement sites. Only brief descriptions are given here. It should be noted that data quality has continuously improved over the decades of measurements due to steadily improving quality assurance procedures, e.g. systematic audits instituted by the GAW network in the early 1990 s.

In this work we have not considered $\mathrm{O}_{3}$ sonde data sets, which have provided some of the longest-term data records. Sonde data have been incorporated into previous discussions of long-term tropospheric $\mathrm{O}_{3}$ changes (Logan et al., 1999; Naja et al., 2003; Oltmans et al., 2006). We have generally limited our consideration to in-situ measurements at surface sites. The one exception is a North American free troposphere (FT) data set, which incorporated mainly MOZAIC plus other aircraft, $\mathrm{O}_{3}$ sonde and LIDAR data (Cooper et al., 2010). Since at least the 1990s in-situ measurements are generally made by UV absorption techniques, which are expected to be much less sensitive to interference and calibration uncertainties, compared to the uncertainties arising from changes in sonde instrumentation and operating procedures. Logan et al. (2012) have carefully compared $\mathrm{O}_{3}$ measurements from sondes, MOZAIC aircraft and alpine sites in Eu- rope. They conclude that $\mathrm{O}_{3}$ data from MOZAIC aircraft, the alpine sites (both utilizing UV absorption instruments) and most sonde stations are self-consistent since about 1998; however, they and Schnadt Poberaj et al. (2009) identified problems with sondes in earlier years. Ozone series collected with ECC type sondes of several series are presently homogenized since the 1990s. Consequently, we conclude that it is prudent to not include sonde measurement records in the analysis presented in this paper with the one exception noted above with regard to the North American FT data set. However, it may be valuable to utilize $\mathrm{O}_{3}$ sonde data sets to examine inter-annual variability over a limited number of years or seasonal cycles during specific periods.

From a multi-decade perspective, Europe has the most extensive record of ambient $\mathrm{O}_{3}$ measurements. The longest quasi-continuous record was begun in 1956 at Arkona, a near sea level site on the Baltic Sea coast in northern Germany. These measurements were initially conducted by wellcalibrated, well-characterized wet chemical methods (Feister and Warmbt, 1987). Measurements at that site ended in 1990. In 1991 measurements were begun at a nearby, similar EMEP (http://www.emep.int/index.html) site at Zingst, Germany, also a Baltic coastal site. The data from these two sites are combined here to give one continuous record covering 1956-2010, but it must be noted that changes in site and measurement techniques add uncertainty to this data record. For example as discussed by Feister and Warmbt (1987), the earlier wet chemical methods suffered from negative interferences from sulfur dioxide $\left(\mathrm{SO}_{2}\right)$. However, the $\mathrm{SO}_{2}$ concentrations at Arkona were so low that this interference was found to be negligible. $\mathrm{A} \mathrm{CrO}_{3}$ filter (for $\mathrm{SO}_{2}$ removal) was installed in 1972 without detectable change in measurements. The concentration of the reagent solution was doubled in the mid 1970s, which led to a significant increase in observed maximum $\mathrm{O}_{3}$ concentrations, but there was no indication that the mean concentrations were affected. Finally, a change from four measurements per day $(0,6,12,18 \mathrm{~h})$ to continuous recording was made in 1982, again without significant change (see Fig. 8 of Feister and Warmbt, 1987). The site change from the Arkona to Zingst does not show significant differences in values, nor in the trend. Nevertheless, the relative dip in $\mathrm{O}_{3}$ seen at Arkona in all seasons in the 1980s is not understood, and perhaps does indicate analytical problems; however the exclusion of those data has little influence on the following analysis, so this potential problem is of small consequence for our purposes. Given these site locations and that no baseline selection has been performed, this dataset includes a contribution from regional emission changes over the period of the measurements, and is best described as representative of regional ozone in northwestern Europe.

Even earlier measurements were conducted during short periods at Arosa, Switzerland in springtime in the 1930s and 1950s (Staehelin et al., 1994) and at the Jungfraujoch, Switzerland in summertime in the 1930s (Crutzen, 1988). 
Table 1. Ozone data sets investigated in this work.

\begin{tabular}{|c|c|c|c|c|}
\hline Monitoring site & Dates & Lat./Long. & Elev. $(\mathrm{km})$ & Original analysis, site description and/or data source \\
\hline \multicolumn{5}{|c|}{ Europe } \\
\hline $\begin{array}{l}\text { Arkona-Zingst, } \\
\text { Germany }\end{array}$ & $1956-2010$ & $\begin{array}{l}54^{\circ} 26^{\prime} \mathrm{N} \\
12^{\circ} 44^{\prime} \mathrm{E}\end{array}$ & 0.00 & Feister and Warmbt (1987) \\
\hline $\begin{array}{l}\text { Mace Head, } \\
\text { Ireland }\end{array}$ & 1989-2010 & $\begin{array}{r}53^{\circ} 10^{\prime} \mathrm{N} \\
9^{\circ} 30^{\prime} \mathrm{W}\end{array}$ & 0.02 & Derwent et al. (2007) \\
\hline Hohenpeissenberg, & $1971-2010$ & $47^{\circ} 48^{\prime} \mathrm{N}$ & 1.0 & Gilge et al. (2010) \\
\hline Germany & & $11^{\circ} 01^{\prime} \mathrm{E}$ & & (data available at: http://ds.data.jma.go.jp/gmd/wdegg/) \\
\hline Arosa, & 1950s; & $46^{\circ} 47^{\prime} \mathrm{N}$ & 1.8 & Staehelin et al. (1994) \\
\hline Switzerland & $1989-2010$ & $9^{\circ} 41^{\prime} \mathrm{E}$ & & \\
\hline $\begin{array}{l}\text { Zugspitze, } \\
\text { Germany }\end{array}$ & $1978-2009$ & $\begin{array}{l}47^{\circ} 25^{\prime} \mathrm{N} \\
10^{\circ} 59^{\prime} \mathrm{E}\end{array}$ & 3.0 & Gilge et al. (2010); (data available from H.-E. Scheel at IMK-IFU) \\
\hline $\begin{array}{l}\text { Jungfraujoch, } \\
\text { Switzerland }\end{array}$ & $\begin{array}{r}1930 s ; \\
1990-2010\end{array}$ & $\begin{array}{r}46^{\circ} 33^{\prime} \mathrm{N} \\
7^{\circ} 59^{\prime} \mathrm{E}\end{array}$ & 3.6 & $\begin{array}{l}\text { Brönnimann et al. (2002); Gilge et al. (2010); Cui et al. (2011) } \\
\text { (data available from: http://ds.data.jma.go.jp/gmd/wdcgg/) }\end{array}$ \\
\hline \multicolumn{5}{|c|}{ North America } \\
\hline US Pacific & $1985-2010$ & $38-48^{\circ} \mathrm{N}$ & 0 to 0.24 & Parrish et al. (2009), NOAA GMD ${ }^{\mathrm{a}}$ \\
\hline Coast MBL & & $123-124^{\circ} \mathrm{W}$ & & \\
\hline Lassen NP & $1988-2010$ & $40^{\circ} 32^{\prime} \mathrm{N}$ & 1.76 & Jaffe et al. (2003), NPS ${ }^{b}$ \\
\hline California US & & $121^{\circ} 35^{\prime} \mathrm{W}$ & & \\
\hline North American FT & 1984-2008 & $\begin{array}{r}25-55^{\circ} \mathrm{N} \\
90-130^{\circ} \mathrm{W}\end{array}$ & 3.0 to 8.0 & Cooper et al. (2010) \\
\hline \multicolumn{5}{|c|}{ Asia } \\
\hline Japanese MBL & $1998-2011$ & $\begin{array}{r}38-45^{\circ} \mathrm{N} \\
138-142^{\circ} \mathrm{E}\end{array}$ & 0 to 0.11 & Tanimoto et al. (2009), EANET ${ }^{\mathrm{c}}$ \\
\hline Mt. Happo, Japan & $1991-2011$ & $\begin{array}{r}36^{\circ} 42^{\prime} \mathrm{N} \\
137^{\circ} 48^{\prime} \mathrm{W}\end{array}$ & 1.85 & Tanimoto (2009), Tanimoto et al. (2009), EANET ${ }^{\mathrm{c}}$ \\
\hline \multicolumn{5}{|c|}{ Downwind of North America } \\
\hline Bermuda & $1989-2010$ & $\begin{array}{r}32^{\circ} 16^{\prime} \mathrm{N} \\
64^{\circ} 53^{\prime} \mathrm{W}\end{array}$ & 0.03 & Oltmans et al. (2006), NOAA GMD ${ }^{a}$ \\
\hline $\begin{array}{l}\text { Sable Island, Nova Scotia, } \\
\text { Canada }\end{array}$ & $1991-2008$ & $\begin{array}{l}43^{\circ} 56^{\prime} \mathrm{N} \\
60^{\circ} 01^{\prime} \mathrm{W}\end{array}$ & 0.02 & Parrish et al. (1998), NSE ${ }^{\mathrm{d}}$ \\
\hline
\end{tabular}

These early measurements were made both by long-path absorption spectrophotometry and by wet-chemical techniques, which compared well with each other as reviewed by Crutzen (1988). Here we combine these early measurements with more recent data at these two sites to give long-term, but discontinuous records. The other European sites include Mace Head, Ireland, an Atlantic coastal site that receives relatively remote $\mathrm{MBL}$ air with measurements beginning in April 1987, and Hohenpeissenberg and Zugspitze, Germany, where measurements were begun in the 1970s. The four central European sites are at elevated altitudes (two, Zugspitze and Jungfraujoch, are high alpine sites), and are thus expected to sample air with relatively small local continental influence, at least a significant fraction of the time (Cui et al., 2011). Both Hohenpeissenberg and Arosa are at lower elevations than the two alpine sites, and likely are more strongly affected by regional $\mathrm{O}_{3}$ influences. The Hohenpeissenberg data have been filtered to remove very local contamination (see description at WDCGG website: http://ds.data.jma.go.jp/gmd/wdcgg/cgi-bin/ wdcgg/accessdata.cgi?index $=$ HPB647N00-DWD\&param= $200612120588 \&$ select $=$ parameter $\&$ parac $=$ processing.

These European data sets have been selected for baseline conditions only at Mace Head. Cui et al. (2011) selected baseline conditions at Jungfraujoch from 1990-2008, but in this work, we examine the full data set because the older summer data from the 1930s cannot be baseline selected, and two additional years of data are available in the full data set. Baseline selection was also performed by various methods for subsets of data from other sites; comparisons between baseline filtered and unfiltered data are discussed in Sect. 4.4. 
North America has a limited record of $\mathrm{O}_{3}$ measurements that can be taken to represent baseline conditions. Relatively short records are available from five coastal MBL sites along the US Pacific Coast. By showing that there were no statistically significant differences between monthly average $\mathrm{O}_{3}$ determinations in onshore airflow when measurements were concurrently available from separate sites, Parrish et al. (2009) were able to combine these measurements into a single record representative of MBL baseline $\mathrm{O}_{3}$ concentrations. Cooper et al. (2010) combined all available free troposphere data collected during springtime over western North America. This data set does have a long gap between the first year (1984), when a large data set was collected during the NASA CITE-2 study, and 1995, when the MOZAIC program and two sonde series were initiated. In the analyses discussed in the following sections, derived $\mathrm{O}_{3}$ changes are still significant if the 1984 measurements are omitted, and the results do not statistically significantly differ from that derived from the full data set (see Cooper et al., 2010). These North American MBL and FT records began in 1985 and 1984, respectively. There is one elevated site in western North America (Lassen Volcanic National Park in California) that receives relatively undisturbed inflow from the Pacific; measurements there were begun in 1988. The MBL and FT data sets have been selected for baseline conditions, but not the Lassen NP data.

Two Japanese data sets are considered (Tanimoto, 2009; Tanimoto et al., 2009) that are representative of inflow to Japan, which is directly downwind of the East Asian mainland. One is a mountain site (Mt. Happo) with measurements available from 1991-2011, and the other is derived from three MBL sites at the west coast of Japan with measurements from 1998-2011. To increase the robustness of the latter data set, measurements from the three northern MBL sites (Rishiri Island, Cape Tappi, and Sado Island, $38-45^{\circ} \mathrm{N}$ latitude) reported by Tanimoto et al. (2009) are combined into a single data set. This is accomplished by assuming that a seasonal average $\mathrm{O}_{3}$ determination at any one of the three sites constitutes an independent determination of the MBL $\mathrm{O}_{3}$ concentration in this region; the average of all available averages for each season (from either two or all three of the sites) is taken as the best estimate of the regional MBL seasonal average. Analysis of these two Japanese data sets has been extended through 2011 because of their relatively short temporal extent, and because instrumental problems were identified in the measurements at Mt. Happo in 2007 and 2010, which led to the exclusion of those data. Neither of these Japanese data sets has been selected for baseline conditions. We also will briefly discuss measurements from another Japanese MBL site (Ryori) on the east coast of Japan, which was suggested by Logan (2012).

Different strategies have been utilized to select baseline conditions. For Mace Head Derwent et al. (2007) used pollution filtering and the NAME Lagrangian dispersion model to filter data to exclude times when a significant fraction of the sampled air had origins over mainland Europe, was transported from southern latitudes, or when emissions from the Mace Head region remained close to the station. It was not possible to completely exclude potential interferences from local or sporadic emissions such as shipping or aircraft. Here we use Mace Head data for February 1989 onwards filtered utilizing only the NAME Lagrangian dispersion model and present a comparison between long-term changes calculated from filtered and unfiltered Mace Head data (Sect. 4.4). For the US Pacific Coast MBL, Parrish et al. (2009) selected data collected during a high, onshore local wind window. This wind selection criterion was shown to give comparable results to selection by criteria based upon several continental tracers. For the North American FT data set, Cooper et al. (2010) used the FLEXPART Lagrangian particle dispersion model to exclude data with a recent (5 days), strong influence from the North American boundary layer. These selected data sets are taken to provide the best characterization of baseline $\mathrm{O}_{3}$, and are analyzed here. For the other eight data sets no baseline selection method is available for the complete data sets so unfiltered data have been analyzed. Section 4.4 discusses subsets of data sets with and without filtering to investigate the possible impact of the lack of baseline selection.

Two additional, more limited data sets from sites downwind from North America (Sable Island, Nova Scotia, Canada and Bermuda) are also briefly discussed. These sites provide useful comparisons to the two Japanese sites that lie directly downwind from Asia.

\section{Analysis approach and selected results}

The goal of the present analysis is to quantify as accurately and precisely as possible the long-term changes in observed $\mathrm{O}_{3}$ concentrations at northern mid-latitudes that are representative of baseline conditions. A major problem in such quantification is deriving the long-term change in the presence of short-term (inter-annual and shorter) variability that is much larger than long-term changes. Further, the studies differ in the time period covered, and in the degree to which varying regional influences may obscure baseline trends. Building upon the approach of Parrish et al. (2009), five strategies are employed here to surmount these problems. First, the longest possible time periods covered by observational records are analyzed to allow the long-term changes to be as large as possible relative to shorter-term variability. Second, where possible baseline data sets are considered to avoid confounding changes and variability associated with local influences. Third, changes in three-month seasonal averages (March, April and May equal spring, etc.) are investigated. Compared to a shorter averaging period (e.g. monthly) a seasonal averaging period minimizes interannual variability, while still allowing investigation of the seasonal dependence of long-term changes; this is important for $\mathrm{O}_{3}$, which exhibits a strong 
seasonality. It should be noted that winter of a given year includes January and February of that year, and December of the preceding year. A given seasonal average is included only if data are available for each of the three months of the season. Fourth, only a minimal number of parameters are included in the derived functional forms intended to represent long-term changes; as the number of parameters extracted from a given data set is increased, the precision with which any one parameter can be derived generally decreases (i.e. the confidence limit of the parameter estimate increases). The final strategy is perhaps more subtle; attention is paid to the continuity of the derived functional form over the complete data record. A continuous long-term change (i.e., a change with no discontinuous jumps) is expected, since the physical causes of long-term changes in $\mathrm{O}_{3}$ are not expected to vary in a discontinuous manner. These physical causes are, for example, changes in anthropogenic $\mathrm{O}_{3}$ precursor emissions or stratospheric-tropospheric transport that are expected to change only gradually, so the resulting changes in $\mathrm{O}_{3}$ are expected to be relatively gradual as well.

To implement the above strategies, we rely on simple statistical approaches: linear (two parameter) and quadratic (three parameter) least-squares regressions to the full time periods of the measurement records. These parameters and their confidence limits constitute the quantification of the long-term $\mathrm{O}_{3}$ changes. The $95 \%$ confidence limits are derived from standard, unweighted fits to seasonal average $\mathrm{O}_{3}$ as a function of year. An average is included for each season with measurements available for at least two-thirds of that seasonal period. All data sets are arbitrarily referenced to the year 2000. The linear least-squares fit is to a two-parameter equation:

$\left[\mathrm{O}_{3}\right]=$ slope $\cdot($ year -2000$)+$ intercept.

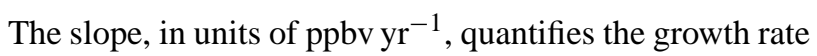
of $\mathrm{O}_{3}$ and is the best measure of the average annual increase in $\mathrm{O}_{3}$ mixing ratio over the period of the data record, while the intercept provides the interpolated, seasonally averaged $\mathrm{O}_{3}$ mixing ratio in the year 2000. The utilization of a linear fit does not assume that the temporal change was necessarily linear over the data record, and does not imply that a trend will continue linearly into the future. The quadratic least-squares fit is to a three-parameter equation:

$\left[\mathrm{O}_{3}\right]=$ intercept $+\mathrm{K} 1 \cdot($ year -2000$)$

$+\frac{1}{2} \cdot$ acceleration $\cdot(\text { year }-2000)^{2}$.

Here again the intercept provides the interpolated, seasonally averaged $\mathrm{O}_{3}$ mixing ratio in the year 2000, although the numerical value may differ from that derived from the linear regression. $\mathrm{K} 1$ is the slope (i.e. the value of $\mathrm{d}\left[\mathrm{O}_{3}\right] \mathrm{d} t^{-1}$ ) in the year 2000; it is the interpolated, seasonally averaged rate of increase of $\mathrm{O}_{3}$ in that year, but this rate of increase changes with time rather than representing the average yearly increase in $\mathrm{O}_{3}$, as is the case in Eq. (1). The acceleration, with units of $\mathrm{ppbv} \mathrm{yr}^{-2}$, quantifies the rate of change in the growth rate of $\mathrm{O}_{3}$ and equals the average rate of increase of the slope over the period of the data record. The term "acceleration" is often interpreted only with a positive magnitude; here it is taken to mean "growth rate change", and can thus be either positive or negative. As discussed later, several data records yield negative accelerations, which indicates that the rate of increase in $\mathrm{O}_{3}$ slowed over those data records, and in some cases reversed so that $\mathrm{O}_{3}$ at present is decreasing at some sites in some seasons. All of the regressions were calculated with Igor Pro, a technical graphing and data analysis package (http://www.wavemetrics.com/), which gives the parameters with $95 \%$ confidence limits through standard statistical methods.

Importantly, fitting Eq. (1) or (2) to any particular data set gives a line or curve that is independent of the choice of reference year. Thus, the slope and its confidence limit in Eq. (1) and the acceleration and its confidence limit in Eq. (2) do not vary with the reference year chosen. However, the intercept in Eq. (1) and the intercept and K1 in Eq. (2) do change with that choice. The year 2000 was selected here because that year is well inside the time period covered by all data records; selection of a reference year near one end of the data record would degrade the confidence limits for the intercept determined in the linear regression and the intercept and K1 determined in the quadratic regression.

Three of the eleven data sets (Arkona-Zingst, US Pacific Coast MBL and Japanese MBL) comprise data collected from two, five and three different sites, respectively. Parrish et al. (2009) compared overlapping portions of the data records from individual sites within the US Pacific Coast MBL to demonstrate that there were no statistically significant differences in baseline $\mathrm{O}_{3}$ between the sites, so that they can be confidently combined into a single data record. For the three Japanese sites, which cover nearly identical time periods, there are small differences in the derived intercepts (range of 2.6 to $8.2 \mathrm{ppbv}$ depending on season), and due to the short measurement records the derived long-term changes from each site vary significantly, so the data are combined to give a single average data set as described in the preceding section. Unfortunately, the measurement records at Arkona and Zingst do not overlap, so no direct comparison of simultaneous data is possible. However, both stations are located directly on the Baltic coast, approximately $50 \mathrm{~km}$ apart, in a rural area with low population density and little local traffic. This similarity provides confidence in combining the data from the two sites into one, longer-term measurement record.

Figures S1-S11 of the Supplement present the results of the linear and quadratic regressions for all eleven data sets. Annotations in each figure give the derived parameters of those regressions, along with their confidence limits. The figure captions discuss details of the data sets and the regressions. In the following sections some examples of this analysis and selected results are discussed further. 


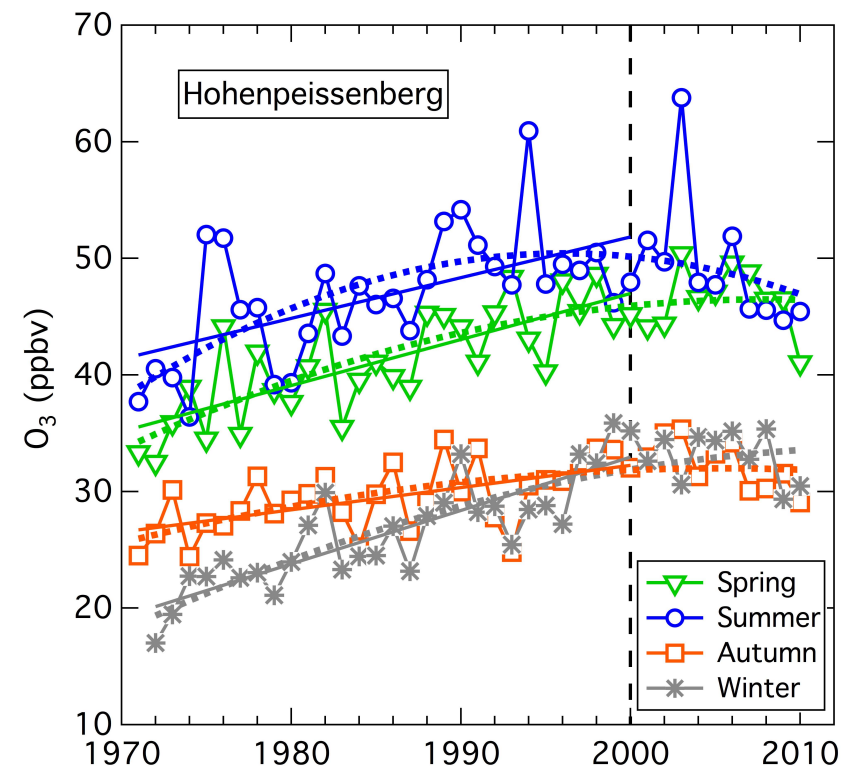

Fig. 2. Seasonal $\mathrm{O}_{3}$ averages measured at Hohenpeissenberg Germany. The solid lines indicate linear regressions for the data up to and including year 2000. The dotted lines give the quadratic regressions for the entire data sets.

\subsection{Hohenpeissenberg analysis}

The application of the above strategies is well exemplified by the analysis of the four-decade Hohenpeissenberg data set illustrated in Fig. 2. Table 2 gives the parameters of the two regressions. The linear regressions indicate that over at least the first approximately $30 \mathrm{yr}$ of the data record, an increase in $\mathrm{O}_{3}$ was observed in all four seasons. In each season the derived increase (i.e. linear regression slope) was highly statistically significant, with all slopes much larger than the respective $95 \%$ confidence limits. The average annual increase over those $30 \mathrm{yr}$ was a maximum of $0.46 \pm 0.11 \mathrm{ppbv} \mathrm{yr}^{-1}$ in winter, slightly less in spring and summer $(0.39 \pm 0.13$ and $0.35 \pm 0.19 \mathrm{ppbv} \mathrm{yr}^{-1}$, respectively), and a minimum in autumn $\left(0.19 \pm 0.10 \mathrm{ppbv} \mathrm{yr}^{-1}\right)$, although only the difference between autumn and the other 3 seasons is statistically significant. The $r^{2}$ values indicate that the linear increases account for between approximately $33 \%$ (in summer) and $72 \%$ (in winter) of the variance of the seasonally averaged $\mathrm{O}_{3}$ between 1971 and 2000. The present results are in good agreement with the conclusions of a previous analysis of the Hohenpeissenberg $\mathrm{O}_{3}$ data set by Gilge et al. (2010).

The negative accelerations derived from the quadratic fits (Eq. 2) indicate that the rate at which the $\mathrm{O}_{3}$ concentration increased at Hohenpeisenberg slowed over the 40-yr record and has changed sign (i.e. begun to decrease) in some seasons. This decrease in the rate, already noted in other work (Logan et al., 2012 and papers cited therein), is statistically significant in all seasons (only marginally so in autumn). The quadratic fits with negative acceleration values indicate that
Table 2. Parameters of linear regression using least-squares fits to the Hohenpeissenberg data set. CL indicates the $95 \%$ confidence limits of the respective parameters, and $r$ is linear correlation coef-

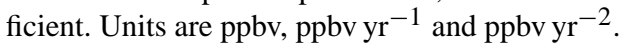

\begin{tabular}{lrrr}
\hline \multicolumn{4}{c}{ Linear fit $-1971-2000$} \\
\hline Season & intercept \pm CL & slope \pm CL & $r^{2}$ \\
\hline spring & $47.0 \pm 2.2$ & $0.39 \pm 0.13$ & 0.58 \\
summer & $51.8 \pm 3.3$ & $0.35 \pm 0.19$ & 0.33 \\
autumn & $32.3 \pm 1.7$ & $0.19 \pm 0.10$ & 0.34 \\
winter & $33.0 \pm 1.9$ & $0.46 \pm 0.11$ & 0.72 \\
\hline \multicolumn{5}{c}{ Quadratic fit $-1971-2010$} \\
Season & intercept \pm CL & K1 \pm CL & acceleration \pm CL \\
\hline spring & $45.9 \pm 1.3$ & $0.14 \pm 0.17$ & $-0.018 \pm 0.016$ \\
summer & $50.1 \pm 2.0$ & $-0.14 \pm 0.27$ & $-0.036 \pm 0.024$ \\
autumn & $31.8 \pm 1.0$ & $0.05 \pm 0.14$ & $-0.010 \pm 0.013$ \\
winter & $31.9 \pm 1.1$ & $0.24 \pm 0.15$ & $-0.015 \pm 0.014$ \\
\hline
\end{tabular}

the seasonal $\mathrm{O}_{3}$ mixing ratios have already or may later reach a maximum. The derived coefficients in Table 2 indicate that those maxima were reached in summer 1996, autumn 2005 and spring 2008, and will be reached in winter 2016 (assuming that the quadratic fit accurately extrapolates that seasonal trend). However, these are imprecise estimates with broad $95 \%$ confidence limits for the year of those maxima (derived from a simple propagation of errors ignoring any covariance of the parameters) varying between $8 \mathrm{yr}$ for summer and $18 \mathrm{yr}$ for winter. These maxima are based upon the slowly varying, long-term changes as described by the quadratic fit, which removes interannual variability. Thus, the year with the highest measured $\mathrm{O}_{3}$ concentration likely does not agree with the maximum derived from the quadratic regression. For example, the largest summertime seasonal average occurred in 2003, the year of a notable heat wave in Europe (Tressol et al., 2008), which is later than the regression estimate of 1996.

These quadratic fits indicating decreases in growth rate are the reason we have limited the linear regression to the period of the data record before the year 2000. As we will see in the examination of the regressions to the other data sets, statistically significant negative accelerations are found for sites other than Hohenpeissenberg. In these cases, the linear regressions will generally include only data collected before the year 2000; care must then be taken to interpret the slope of those linear regressions as the average annual increase in $\mathrm{O}_{3}$ mixing ratio over the portion of the data record before 2000 . 
Table 3. Parameters of linear regression using least-squares fits to the Mace Head data set for the indicated time periods. CL indicates the $95 \%$ confidence limits of the respective parameters, and $r$ is

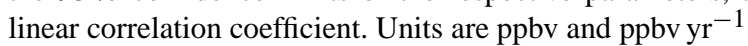

\begin{tabular}{lccc}
\hline \multicolumn{4}{c}{ Linear fit $-1989-2000$} \\
\hline Season & intercept \pm CL & slope \pm CL & $r^{2}$ \\
\hline spring & $45.5 \pm 2.2$ & $0.72 \pm 0.34$ & 0.68 \\
summer & $35.1 \pm 1.9$ & $0.35 \pm 0.30$ & 0.41 \\
autumn & $36.8 \pm 2.4$ & $0.38 \pm 0.37$ & 0.34 \\
winter & $43.7 \pm 1.8$ & $0.88 \pm 0.31$ & 0.82 \\
\hline \multicolumn{5}{c}{ Linear fit $-1989-2010$} \\
Season & intercept \pm CL & \multirow{2}{*}{ slope \pm CL } & \multirow{2}{*}{$r^{2}$} \\
\hline spring & $43.3 \pm 0.9$ & $0.35 \pm 0.14$ & 0.58 \\
summer & $34.3 \pm 0.7$ & $0.21 \pm 0.11$ & 0.43 \\
autumn & $36.2 \pm 0.7$ & $0.27 \pm 0.11$ & 0.56 \\
winter & $41.1 \pm 0.8$ & $0.42 \pm 0.13$ & 0.72 \\
\hline
\end{tabular}

\subsection{Analysis of marine boundary layer data sets}

The Arkona-Zingst data set is the longest, nearly continuous record considered, and thus yields the most precise regression results. The other three MBL data sets, two of which are illustrated in Fig. 3, span shorter time periods than the Arkona-Zingst record resulting in poorer precision of the regression fits as reflected in larger confidence limits for the derived parameters. Figures S1, S2, S7 and S10 provide the details of the regressions. None of the accelerations are significant for the Arkona-Zingst or the US Pacific Coast MBL data sets, so the linear regressions include the full data records. At the Japanese MBL sites negative accelerations are significant in two of the four seasons (Fig. S10). Since this data record did not begin until 1998, the linear regressions include the full data records. At Mace Head negative accelerations are significant in two of the four seasons (Fig. S2). However, the relatively large magnitude of the second order coefficients may be driven by boreal biomass burning events (Derwent et al., 2007) or specific transport patterns (e.g., Hess and Zbinden, 2011; Pausata et al., 2012) that led to seasonally averaged enhanced $\mathrm{O}_{3}$ near the center of the data record. Consequently the selection of the time period to include in the linear regression is not completely clear for Mace Head. Table 3 compares the linear regressions for the entire measurement period and for the portion before 2000 . The precision of the derived parameters is significantly better for the entire period. In further analysis here, we consider the linear regressions over the full measurement periods at all four MBL sites.

Logan (2012) suggests that the measurement record from Ryori Japan is more suitable for analysis of MBL baseline $\mathrm{O}_{3}$ downwind of the Asian continent than the sites selected here. However, Ryori is on the eastern coast of Japan, so out-
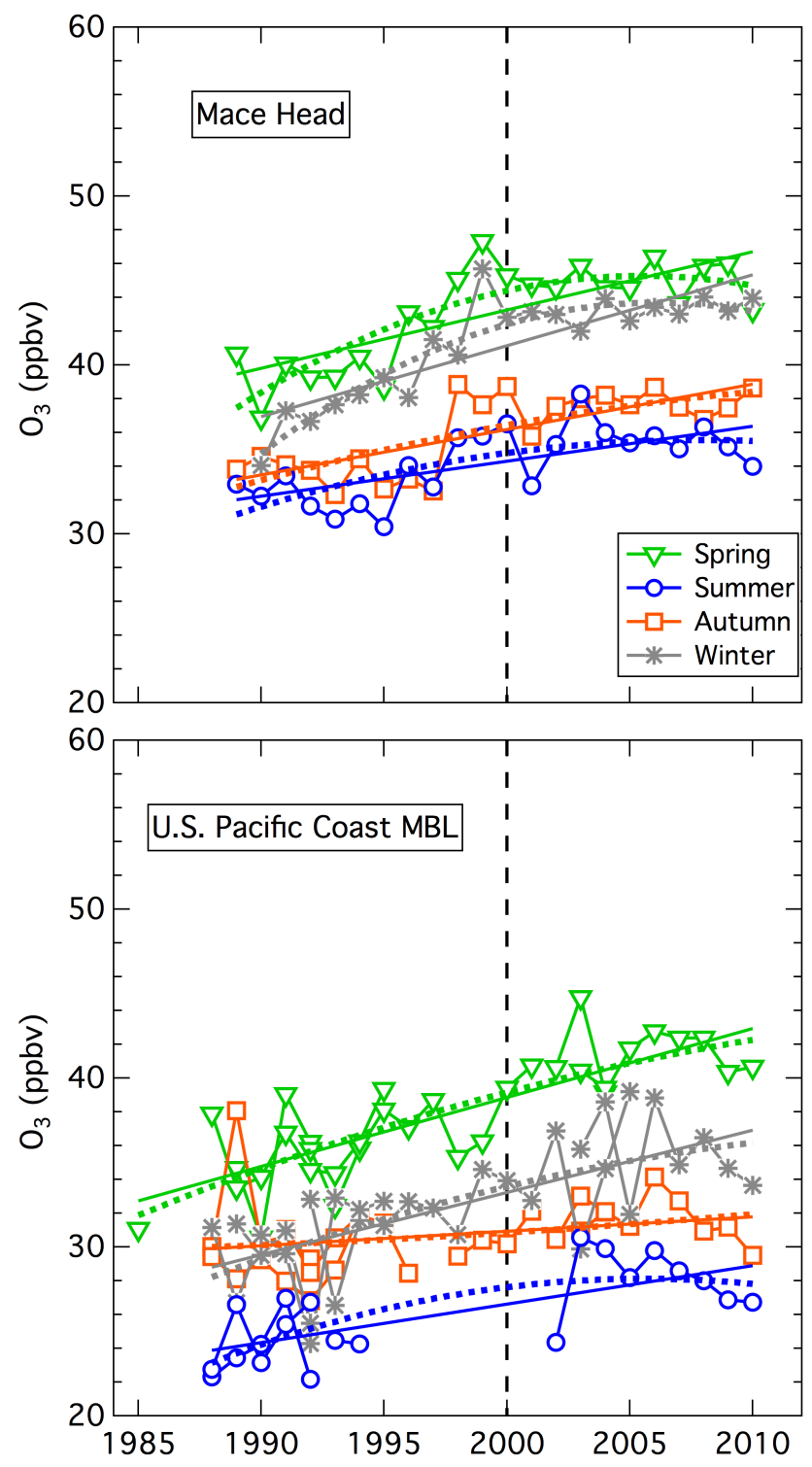

Fig. 3. Seasonal $\mathrm{O}_{3}$ averages measured in the European marine boundary layer (MBL) at Mace Head, Ireland, and in the North American MBL along the US Pacific Coast. Lines indicate linear and quadratic regressions for the complete data sets in the same format as Fig. 2.

flow from the continent must pass over populated Japanese areas before reaching Ryori. Parrish et al. (2012) do show that air masses received at Ryori are strongly influenced by local and likely regional Japanese pollution. Compared to the Japanese MBL analysis included here, Ryori $\mathrm{O}_{3}$ averages $5.4 \pm 0.3$ ppbv lower in all seasons. The Ryori trends in summer and autumn are not statistically significantly different, but the trends in winter and spring are significantly smaller from those determined here. Since our focus is on $\mathrm{O}_{3}$ downwind of the Asian continent, we do not discuss the Ryori data further. 
There are differences in the seasonal cycles and trends between Mace Head baseline and Arkona-Zingst (e.g. compare Figs. 3 and S1). This may be partly due to the differences between baseline-selected and unsorted data, which remove local anthropogenic influences in the Mace Head data. There likely are also contributions from the spatial gradient across Europe in baseline $\mathrm{O}_{3}$ that results from loss, production and vertical transport as air masses move from west to east across Europe. This spatial gradient is apparent across the United Kingdom and may exert an influence not only on absolute $\mathrm{O}_{3}$ levels, but also on trends (Jenkin, 2008).

\subsection{Analysis of higher elevation data sets}

Mountain sites have been chosen for many long-term measurements of $\mathrm{O}_{3}$ since they are more isolated from local and regional influences, and so resulting data sets can provide useful information regarding changes in baseline $\mathrm{O}_{3}$ concentrations in the free troposphere. Figure 4 illustrates analysis of measurements from one mountain site in North America and one at a comparable elevation in Japan. In the analysis presented here, filtering of data for baseline conditions generally has not been performed at the elevated surface sites; the effect of baseline filtering is discussed in Sect. 4.4. We do examine the North American FT data set (Fig. S9) that combines all of the airborne data in the lower free troposphere over western North America and the eastern North Pacific, and these data have been selected for baseline conditions. We also consider three mountain sites located in central Europe in addition to Hohenpeissenberg discussed above; two of these sites had limited measurements conducted in the 1930s and 1950s. Figures S4-S6, S8, S9 and S11 illustrate the details of the linear and quadratic regressions, and the figure captions give some pertinent details of the data sets.

The results from the three additional European data sets are broadly consistent with those from Hohenpeissenberg, indicating these results are generally representative of the western and central European region. The slopes from the linear regressions are positive in all seasons at all sites, indicating region-wide $\mathrm{O}_{3}$ increases in the decades before 2000 . Statistically significant negative accelerations are found at all European high elevation sites in all seasons, which indicate that the rate of $\mathrm{O}_{3}$ increase has slowed, and in some cases reversed and is now decreasing, throughout the European region. Maxima in the quadratic regression fits occurred in the 1990s or early 2000s in all seasons at all of these sites.

Mt. Happo in Japan shows somewhat contrasting behavior, and there is some uncertainty regarding the most recent data from this site. Figure 4 presents the results for 1991-2011, including those reported by Tanimoto et al. (2009) based on measurements by Nagano Environmental Conservation Research Institute (NECRI) and Acid Deposition Monitoring Network in East Asia (EANET). Instrument problems have been identified in 2007 and 2010, and those data have been excluded. The increase in $\mathrm{O}_{3}$, particularly in spring, is greater
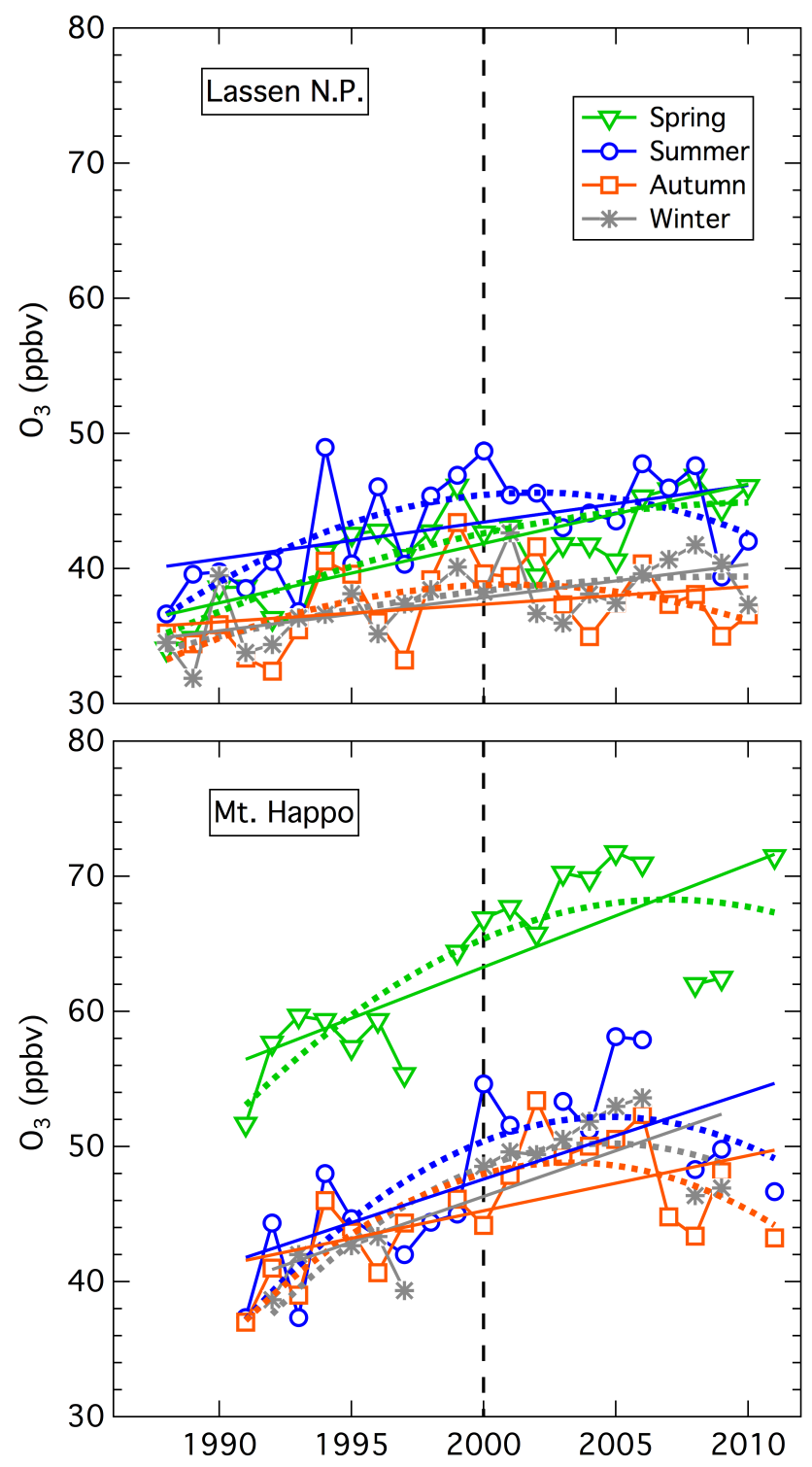

Fig. 4. Seasonal $\mathrm{O}_{3}$ averages measured at high elevation $(\approx 1.9 \mathrm{~km})$ sites in western North America at Lassen NP and in Japan at Mt. Happo. Lines indicate linear and quadratic regressions for the complete data sets in the same format as Fig. 2.

than at any other site, with statistically significant positive slopes from the linear regressions in all seasons, despite the relatively short data record. The rate of $\mathrm{O}_{3}$ increase shows statistically significant indications of decreasing in all seasons (Fig. S11), but the accelerations from the quadratic fits depend strongly on the last few years of data. These data show significant variability, so these negative accelerations must be considered with caution. The $\mathrm{O}_{3}$ changes at this site may reflect the rapid growth in $\mathrm{O}_{3}$ precursor emissions in continental East Asia, which lies upwind of this site (Tanimoto et al., 2009). Ozone at this site, as well as in the Japanese MBL (Fig. S10), exhibits a strong springtime 
maximum, which corresponds to the season of strongest outflow of air from the Asian continent. At Lassen NP (Fig. 4) significant positive changes have occurred in all seasons except autumn (Fig. S8), which is in accord with the changes seen in the US Pacific Coast MBL (Fig. 2). The strongest trend in both of these data sets is in spring, which is in accord with the strong springtime trend seen in the North American FT, results originally presented in Cooper et al. (2010; Fig. S9), and at Mt. Happo. At Lassen NP only in summer and autumn are the negative accelerations from the quadratic fits statistically significant.

\subsection{Comparison of baseline and unfiltered data sets}

Ideally all analyses would be based upon data sets filtered for baseline conditions. However, in the analysis presented up to this point baseline filtering has been done for only three of the eleven data sets; the remaining eight data sets are unfiltered. In essence, we assume that (as a consequence of the location of the sites) the long-term changes in the total data sets provide good approximations to the changes in baseline $\mathrm{O}_{3}$ concentrations at those sites. This assumption can be examined through comparisons of long-term $\mathrm{O}_{3}$ changes derived from filtered and unfiltered data sets, which is possible to some degree for eight of the eleven data sets included in this analysis.

Cui et al. (2011) selected baseline conditions at Jungfraujoch from 1990-2008 by means of 20-day back trajectory analysis, and found that from $20 \%$ (in winter) to nearly $50 \%$ (in summer) of sampled air masses had recent contact with the European boundary layer. Air masses without such contact were considered baseline periods. Figure S16 compares the linear and quadratic fits to $\mathrm{O}_{3}$ measured in the baseline periods to those for the unfiltered data set considered in this paper for identical time periods. Some small differences can be noted in the baseline parameters compared to those from the unfiltered data set: the correlations are stronger, the intercepts are slightly smaller in summer and slightly larger in winter, and the negative accelerations are generally larger. However, there is agreement for all derived parameters within the indicated confidence limits.

Gilge et al. (2010) examined measured $\mathrm{O}_{3}$ concentrations as a function of different wind sectors at Hohenpeissenberg, Zugspitze, Jungfraujoch, as well as another European alpine site (Sonnblick). They found no strong variation of $\mathrm{O}_{3}$ at any of the sites, despite significant variation of precursor concentrations $\left(\mathrm{CO}\right.$ and $\left.\mathrm{NO}_{2}\right)$ with wind direction, at least at Hohenpeissenberg. There has also been an additional limited investigation of the Zugspitze data filtered for baseline conditions, both by selection of night time data (when boundary layer influences are much reduced at the alpine site) and by filtering according to low $\mathrm{CO}$ mixing ratios to select relatively unpolluted air; the trends derived from data sets unfiltered and filtered by the two different criteria were not statistically significantly different (ATMOFAST, 2005). This lack of de- pendence of derived $\mathrm{O}_{3}$ changes upon wind direction, time of day, and $\mathrm{CO}$ concentration argues that at the European alpine sites and at Hohenpeissenberg the $\mathrm{O}_{3}$ changes derived from unfiltered data sets approximately represent changes in baseline $\mathrm{O}_{3}$.

The North American FT data set examined here is also filtered to retain only baseline concentrations, and a slope of $0.70 \pm 0.30 \mathrm{ppbv} \mathrm{yr}^{-1}$ (Fig. S9) was obtained from the linear regression to the springtime (April, May) averages. In the original paper reporting this data set, Cooper et al. (2010) performed linear regressions to the unfiltered data set (slope derived from springtime medians $=0.70 \pm 0.22 \mathrm{ppbv} \mathrm{yr}^{-1}$ ) as well as to the baseline selected data (slope derived

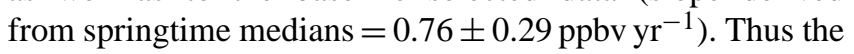
slopes derived from these three linear regressions are in statistical agreement.

The US Pacific Coast MBL data set examined in this work also is selected for baseline conditions. In the original paper reporting the first $23 \mathrm{yr}$ of this 26 -yr data set, Parrish et al. (2009) performed linear regressions to the total springtime data set for comparison to baseline selected data (see Fig. 8 of that reference), which resulted in trends that were not statistically significantly different, although the intercepts derived from the total data sets were significantly smaller than those derived from the baseline selected data.

Jaffe et al. (2003) presented an earlier analysis of the Lassen NP data set examined here. That work compared trends extracted from the total data set and baseline data selected by two different approaches: selection of calculated trajectories with no continental contact and selection of periods of high winds from the direction of the unpolluted Pacific coast. Linear regressions to the unfiltered data set and to the two baseline selected data sets generally indicated statistically significant $\mathrm{O}_{3}$ increases in all seasons, and all derived increases agreed within statistical confidence limits (see Table 2 of that reference). It should be noted that the shorter data record available at that time yielded less precise $\mathrm{O}_{3}$ increase determinations than those reported here.

It is apparent that at least for the seven data sets discussed above, the linear and quadratic regressions to the total data set do indeed provide good approximations for the $\mathrm{O}_{3}$ changes derived from similar regressions to baseline selected data. However, that is not the case for Mace Head. Figure S17 illustrates the regressions for the unfiltered data set, which give significantly different results from the regressions to baseline-selected data illustrated in Figs. 3 and S2. For the baseline data the linear correlation coefficients are larger, the intercepts are larger (most notably in winter), the slopes are much larger, and the negative accelerations are also of larger magnitude, illustrating the importance of sorting baseline from non-baseline data. The large majority of these differences are statistically significant. The unsorted data show no statistically significant slowing in the growth rate of $\mathrm{O}_{3}$. Controlling European regional $\mathrm{NO}_{\mathrm{x}}$ emissions likely has had 

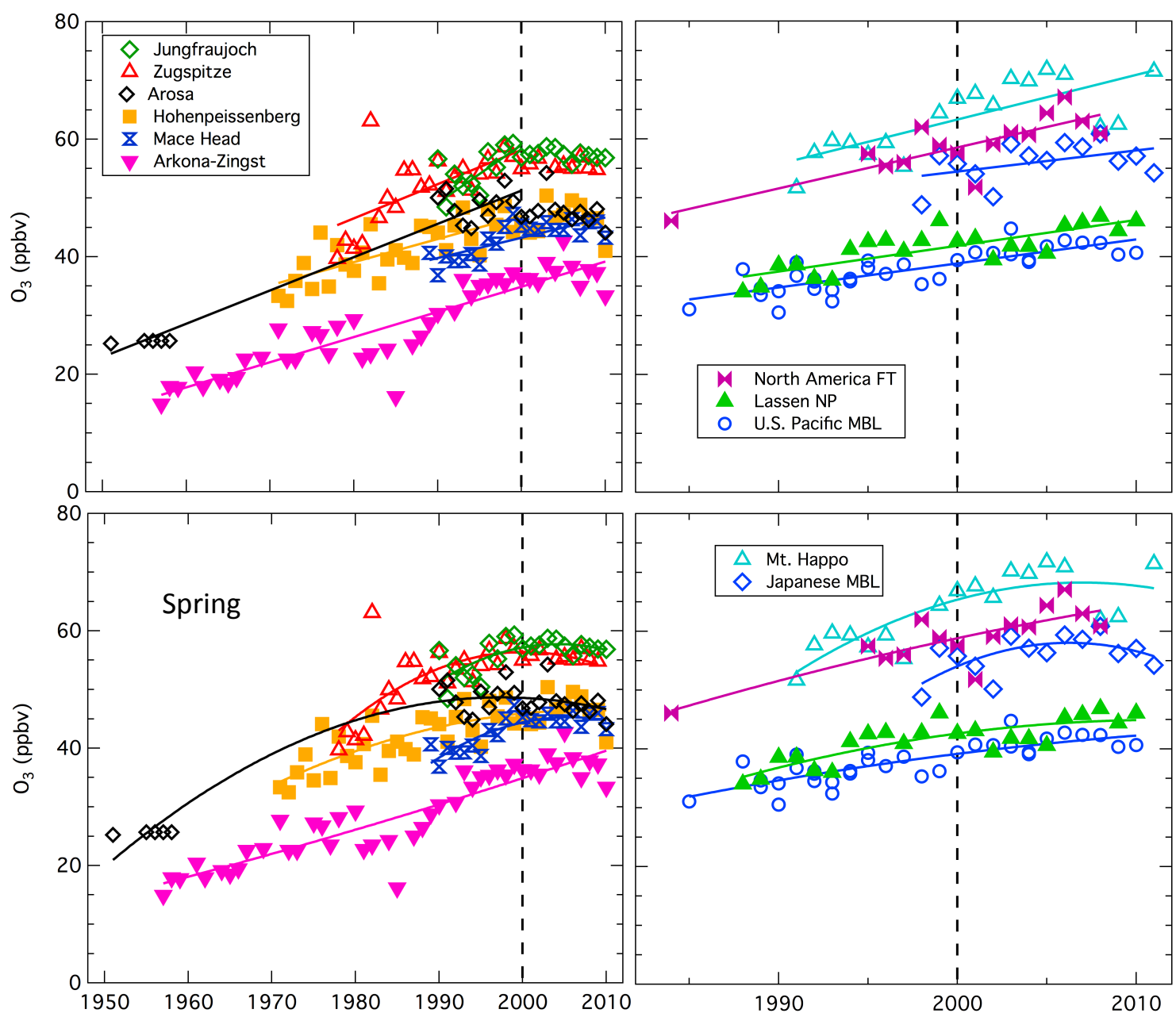

Fig. 5. Comparison of springtime trends in $\mathrm{O}_{3}$ concentrations measured at all sites in Europe (left panels) and western North America and Japan (right panels). The lines (in color) indicate the linear (upper panels) and quadratic (lower panels) regressions to the data.

an influence on unfiltered $\mathrm{O}_{3}$ levels, at least partly due to a decrease in the intensity of $\mathrm{NO}_{\mathrm{x}}$-driven $\mathrm{O}_{3}$ titration events.

From this set of comparisons we can draw tentative conclusions. Regressions to $\mathrm{O}_{3}$ data sets that have not been selected for baseline conditions do provide accurate measures of long-term baseline $\mathrm{O}_{3}$ changes at elevated sites. However, total data sets from boundary layer sites that receive air masses recirculated from the local continent (e.g., Mace Head) must be analyzed with caution. For our purposes in this paper, caution must be applied to the results from Arkona-Zingst, since baseline selection has not been accomplished, and changing measurement procedures add additional uncertainty. The Hohenpeissenberg data set is only filtered for local contaminations, but agreement of $\mathrm{O}_{3}$ data from different wind sectors (rural and slightly polluted) indicates influences from regional emissions are small (Gilge et al., 2010). Finally, it is interesting to note that the Mace Head comparison indicates that, compared to the analysis of the baseline-selected data set, analysis of the unfiltered data set underestimates, rather than overestimates, the magnitude of long-term $\mathrm{O}_{3}$ changes. Different considerations must be applied to the two Asian data sets, since they are in the outflow region from the Asian continent so the definition of baseline is not clear in this environment.

\section{Results, discussion and comparison to other analyses}

Hohenpeissenberg (Fig. 2) exemplifies three important characteristics of the long-term $\mathrm{O}_{3}$ changes determined from these analyses. First, as the positive slopes derived from the linear regressions clearly indicate, present $\mathrm{O}_{3}$ mixing ratios are significantly larger than they were at the beginning of the measurement records. Second, as the negative accelerations indicate, the $\mathrm{O}_{3}$ concentration increase has apparently ended, most noticeably over Europe, and there are indications that concentrations have begun to decrease. Sections 5.1 and 5.2 compare the slopes, intercepts and changes in growth rates (i.e. the accelerations from Eq. 2) derived from all data sets. 
The dependence of these parameters on continent and elevation of the measurement location is also discussed. Third, seasonal differences in $\mathrm{O}_{3}$ changes have resulted in substantial changes in the seasonal cycle in $\mathrm{O}_{3}$ concentrations. Section 5.3 further investigates the changes in the seasonal cycle at different locations.

\subsection{Comparisons of $\mathrm{O}_{3}$ changes throughout northern mid-latitudes}

The springtime $\mathrm{O}_{3}$ averages and the linear and quadratic fits are compared for all eleven data sets in Fig. 5. In this season intercontinental flow is most important (see HTAP, 2010) and influences from local and regional photochemical $\mathrm{O}_{3}$ production are relatively small. Figure 5 indicates that from the earliest measurements in the 1950s until at least near the end of the 20th century, springtime $\mathrm{O}_{3}$ increased at all sites throughout the northern mid-latitudes. The significant curvature evident in the quadratic fits at many sites, particularly in Europe and perhaps later in Japan, shows that the rate of increase has slowed in the later parts of the records. Similar results, with some significant differences, are seen in all seasons (Figs. S12-S14 of the Supplement). Figures 6-8 compare parameters of the linear and quadratic regressions for all data sets in all seasons.

Generally all eleven data sets show trends of increasing $\mathrm{O}_{3}$ in all seasons (Fig. 7a), although a few of these changes have relatively low statistical significance. The longer European data records indicate that the change occurred throughout the second half of the 20th century. Qualitatively all changes are similar to those of the Arkona-Zingst record, at least until approximately year 2000. There is some indication of greater increases in spring and winter, and smaller increases in summer and autumn. Trends determined from the discontinuous data sets from Arosa and Jungfraujoch are similar to the trends extracted from the continuous data sets. The precision with which the changes can be quantified depends strongly on the length of the data record, with the shorter Japanese and Jungfraujoch (except summer) data records having less precision (larger confidence limits). In considering these derived trends, it must be realized that the lack of a statistically significant change (e.g. the Japanese MBL in Fig. 7a) does not necessarily indicate that there has been no change; rather it may indicate that any long-term change that occurred over the period of the data record is too small to be discerned with strong statistical significance given the length of the data record and the interannual variability that is present in the data sets.

In Fig. 7a there is an indication of increasing positive average $\mathrm{O}_{3}$ trend with elevation of the measurement site. Within each season and continent, the results are plotted according to increasing elevation, so the parallel increase in $\mathrm{O}_{3}$ trend is clear. This elevation dependence in the trends is similar to the elevation dependence of the absolute $\mathrm{O}_{3}$ concentrations as indicated by the year 2000 linear regression inter-

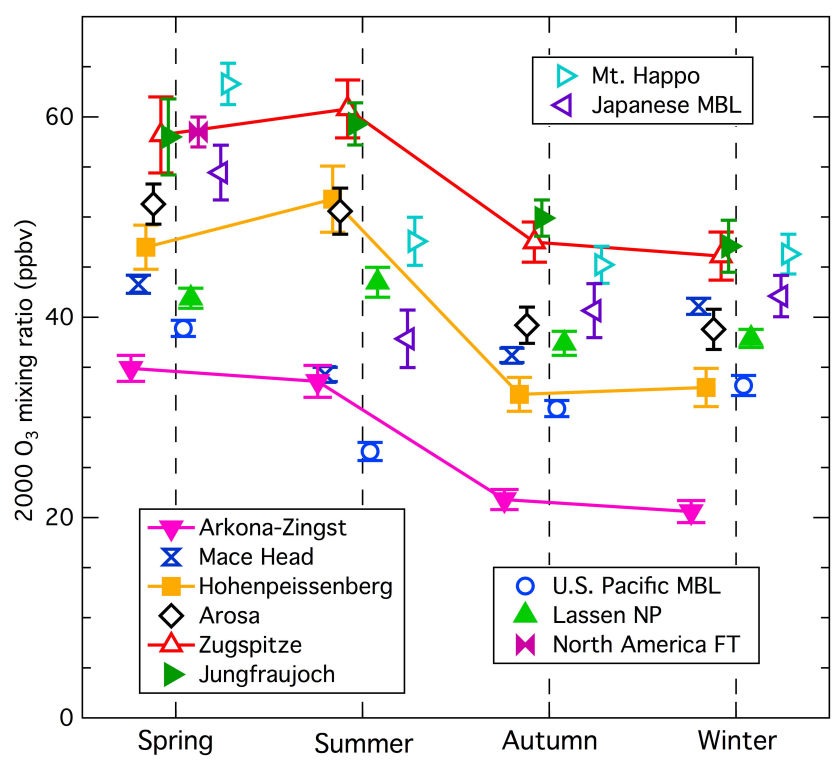

Fig. 6. Summary of year 2000 intercepts of the linear regressions to the eleven northern mid-latitude data sets in each season. The six European data sets are given to the left of the vertical dashed lines, while the three North American and two Japanese data sets are to the right. The sites are positioned in order of increasing elevation within their respective continents. For clarity line segments connect the seasonal intercepts for three of the sites.

cepts (Fig. 6). For the European data sets, the year 2000 intercepts increase with elevation at a rate that varies from $3.5 \pm 0.7 \mathrm{ppbv} \mathrm{O}_{3} \mathrm{~km}^{-1}$ in winter to $7.8 \pm 0.7 \mathrm{ppbv} \mathrm{O}_{3} \mathrm{~km}^{-1}$ in summer, with intermediate dependences in spring and autumn. This increase of $\mathrm{O}_{3}$ with altitude has been discussed previously (e.g. Chevalier et al., 2007). Depending on season, this elevation dependence accounts for $48 \%$ (winter) to $83 \%$ (spring) of the variance in the intercepts among the European data sets. Figure S15 of the Supplement illustrates the elevation dependence of both the intercepts and the slopes from the linear regressions to the European data sets. The increase in slope with altitude is statistically significant, but accounts for a smaller fraction of the variance than was the case for the intercepts: from $34 \%$ in summer to $46 \%$ in spring.

Since both the intercepts and the slopes of the linear regressions increase with elevation, greater similarity between data sets can be found by considering a relative change (i.e., percent change/year relative to a reference value) rather than the absolute changes ( $\mathrm{ppbv} \mathrm{yr}^{-1}$ ) that we have considered to this point. However, it is important to differentiate such a relative change, which is linear relative to a fixed reference, from an exponential change, which can be expressed in percent change/year relative to the resultant, ever changing reference. We will consider a relative, linear change by expressing the change as the slope divided by the year 2000 intercept (expressed as a percentage) where the slope and intercept are from the linear regression already discussed. Figure $7 \mathrm{~b}$ 

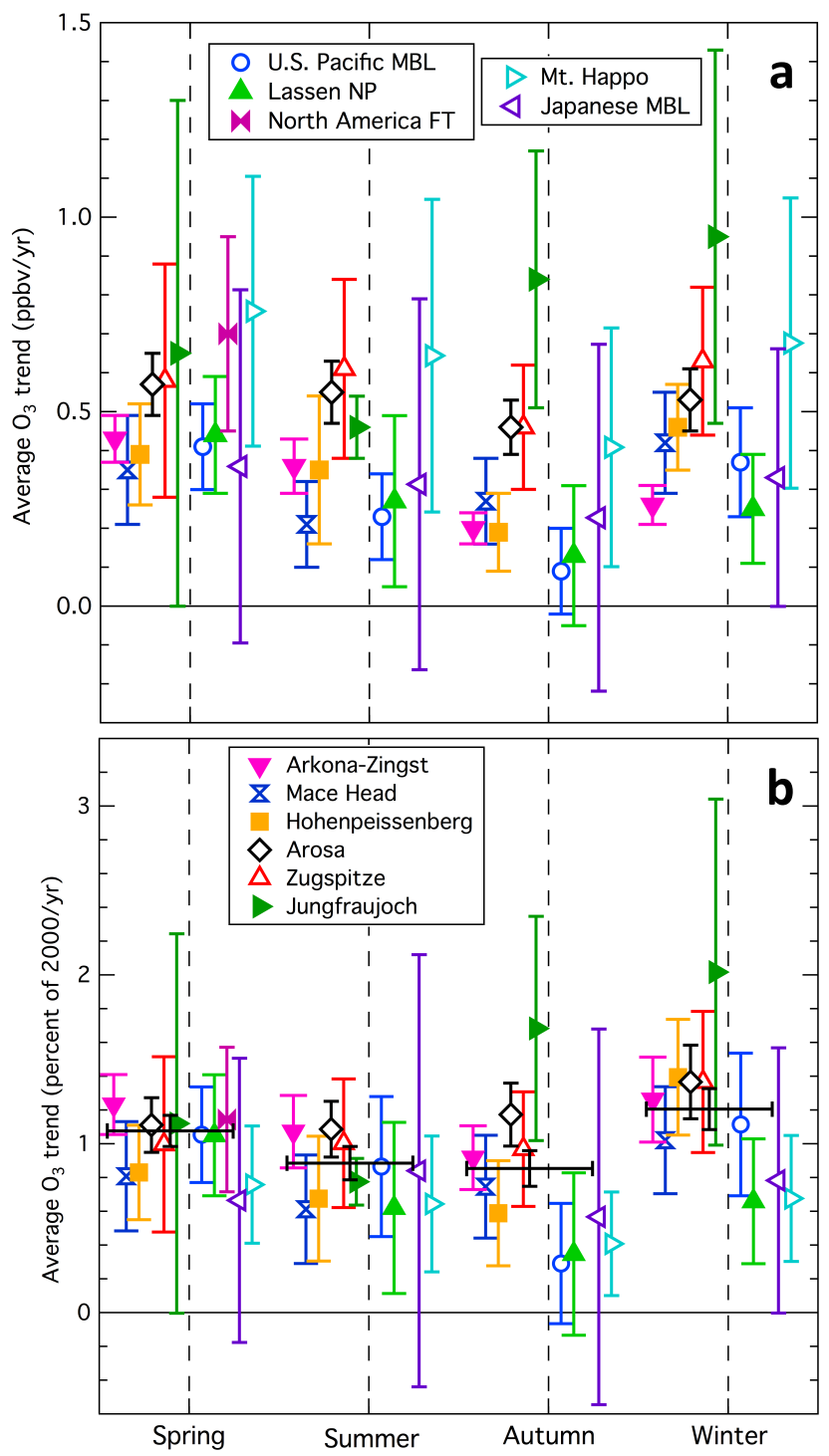

Fig. 7. Summary of average rate of increase in $\mathrm{O}_{3}$ derived for the eleven northern mid-latitude data sets in each season. The order of the sites is the same as in Fig. 6. (a) Rates given as ppbv $\mathrm{yr}^{-1} \mathrm{de}-$ rived from the slopes of linear regressions as described in the text. (b) Rates given as percentage of the year 2000 intercept defined as the ratio of the slope in (a) to the intercept in Fig. 6. The black plus symbols indicate the averages with confidence limits of these rates for all European and North American sites.

displays the average trends relative to the 2000 intercept for all data sets in all seasons. As discussed above, these average trends are for the full measurement periods at each site except at the interior European sites, where the second order term in Eq. (2) is statistically significant and only measurements through the year 2000 are included. These relative changes are similar for all data sets for all seasons.

Until year 2000 all data records show increases in $\mathrm{O}_{3}$, and almost all are significant and similar in magnitude when con-

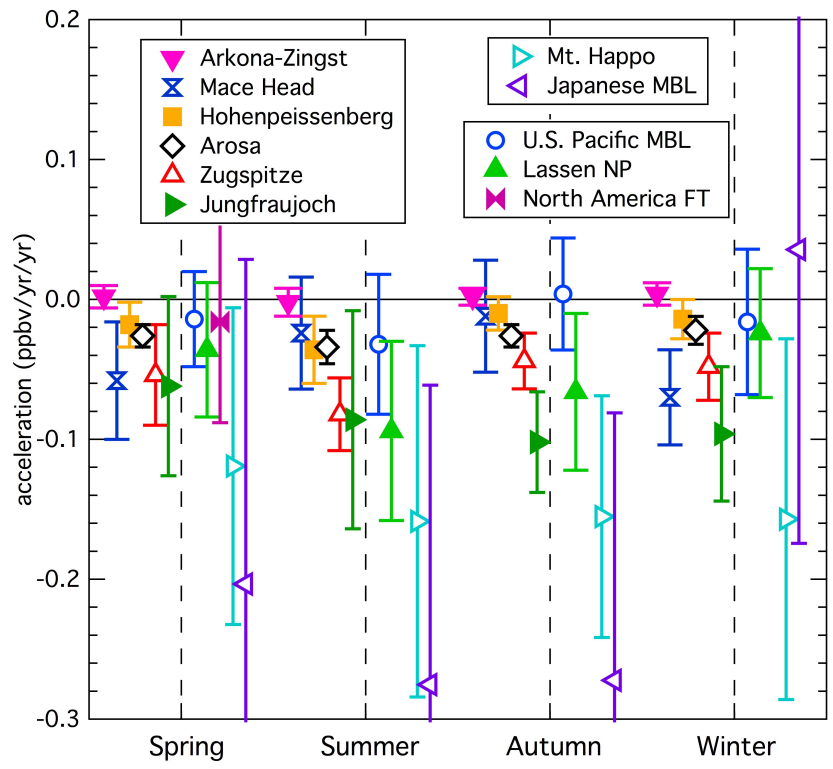

Fig. 8. Summary of the acceleration parameter derived from the quadratic regressions to the eleven northern mid-latitude data sets

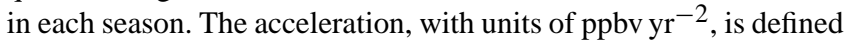
in Eq. (2) of the text, and represents the average rate of increase of the slope over the period of the data record.

sidering percentage changes. If we assume that the nine European and North American data sets provide the best measure of the change in baseline $\mathrm{O}_{3}$ concentrations at northern mid-latitudes, then we can take a weighted average of the relative $\mathrm{O}_{3}$ changes over these data sets for each season. (Here the relative $\mathrm{O}_{3}$ change determined at each site is weighted by the inverse square of its confidence limit. To avoid overweighting the European alpine stations, which are in close proximity, a weighted average of Arosa, Zugspitze and Jungfraujoch is first calculated and assigned a confidence limit equal to that of the smaller of the three stations.) The result is an increase of approximately $1 \% \mathrm{yr}^{-1}$ relative to the respective year 2000 intercepts in each season, specifically $1.08 \pm 0.09,0.89 \pm 0.10,0.85 \pm 0.11$ and $1.21 \pm 0.12 \% \mathrm{yr}^{-1}$ in spring, summer, autumn and winter, respectively. These averages are indicated by the large black plus symbols in Fig. 7b; the $95 \%$ confidence limits of these northern mid-latitude averages are small (about $10 \%$ of the averages). It is notable that $80 \%$ of the seasonal relative changes from all individual data sets agree with the derived northern mid-latitude averages within their respective $95 \%$ confidence limits. This agreement is consistent with the hypothesis that an approximately uniform increase in lower troposphere baseline $\mathrm{O}_{3}$ concentrations has occurred throughout northern mid-latitudes during the last half of the 20th century. The relatively short, recent data set from Mt. Happo, which is strongly influenced by outflow from the East Asian continent where $\mathrm{O}_{3}$ precursor emissions have been rapidly increasing (Ohara et al., 2007), exhibits a large absolute 
increase in spring (the season of maximum continental outflow), but springtime $\mathrm{O}_{3}$ concentrations at Mt. Happo are so large (see Fig. 6) that the relative increase at that site is lower than the average.

As discussed above for Hohenpeissenberg, there are indications that the increase in baseline $\mathrm{O}_{3}$ concentrations has slowed, and at least at the interior European stations, $\mathrm{O}_{3}$ has begun to decrease. Figure 8 compares the changes in the growth rate (i.e. accelerations) derived from the quadratic fits for all data sets and seasons. For all seasons the rate of change in the growth rates are negative with high statistical significance at the four interior European stations (Hohenpeissenberg, Arosa, Zugspitze, and Jungfraujoch). The rates of $\mathrm{O}_{3}$ change at Mace Head have slowed in all seasons, but the slowing is statistically significant only in winter and spring. At Arkona-Zingst, the acceleration is close to zero in all seasons; however, the unexplained dip in $\mathrm{O}_{3}$ concentrations observed during all seasons in the 1980s precludes determination of systematic changes in the slope. The US and North American FT data sets also yield negative values for the acceleration, but they are statistically significant only at Lassen NP in summer and autumn. In the Japanese data sets, the accelerations are also generally statistically significantly negative, but these findings are very sensitive to recent years of data, so must still be considered with caution. Taken together, there is substantial evidence that the increase in northern mid-latitude baseline $\mathrm{O}_{3}$ concentrations has slowed significantly at many sites. Most of the data sets considered here have not been filtered for baseline conditions, so this change may partially reflect reductions in regional $\mathrm{O}_{3}$ precursor emissions. However, since this decrease is seen at high Alpine stations, which are generally well isolated from lo$\mathrm{cal} /$ regional influences, this change likely reflects continental to hemispheric scale $\mathrm{O}_{3}$ changes rather than purely regional effects.

\section{$5.2 \mathrm{O}_{3}$ changes downwind of Asia and North America}

At the Japanese Mt. Happo site, which lies directly downwind of the Asian mainland, $\mathrm{O}_{3}$ has generally increased faster at least in an absolute sense than at the European and North American sites (Fig. 7a). This rapid increase has been attributed, at least partially, to the rapid increase of $\mathrm{O}_{3}$ precursor emissions that has occurred in East Asia over the past two decades (Tanimoto et al., 2009). Cooper et al. (2010) studied changes in free tropospheric springtime $\mathrm{O}_{3}$ of the West Coast of North America. They did not find any decrease in the rate of change of $\mathrm{O}_{3}$ after 2000 (see Fig. 5) and they attributed this feature to the continuing increase in Asian $\mathrm{O}_{3}$ precursor emissions.

Using backward trajectory analysis Chan and Vet (2010) studied long-term $\mathrm{O}_{3}$ changes at 97 regionally representative sites of Canada and the US for period 1997-2006. Their results do not show a consistent picture regarding $\mathrm{O}_{3}$ baseline changes in continental North America, and they concluded
Table 4. Parameters of linear regression using least-squares fits to the Sable Island and Bermuda data sets for the indicated time periods. CL indicates the $95 \%$ confidence limits of the respective parameters, and $r$ is linear correlation coefficient. Units are ppbv and ppbv yr ${ }^{-1}$.

\begin{tabular}{lrrr}
\hline \multicolumn{4}{c}{ Bermuda - 1989-2010 } \\
\hline Season & intercept \pm CL & slope \pm CL & $r^{2}$ \\
\hline spring & $47.1 \pm 2.0$ & $0.27 \pm 0.29$ & 0.21 \\
summer & $26.8 \pm 1.1$ & $0.30 \pm 0.16$ & 0.56 \\
autumn & $35.0 \pm 2.5$ & $0.05 \pm 0.33$ & 0.01 \\
winter & $41.9 \pm 1.8$ & $0.31 \pm 0.25$ & 0.34 \\
\hline \multicolumn{5}{c}{ Sable Island $-1991-2010$} \\
\hline Season & intercept \pm CL & slope \pm CL & $r^{2}$ \\
\hline spring & $37.8 \pm 3.7$ & $-0.21 \pm 0.52$ & 0.10 \\
summer & $30.9 \pm 4.4$ & $-0.21 \pm 0.62$ & 0.19 \\
autumn & $31.2 \pm 1.9$ & $-0.19 \pm 0.26$ & 0.21 \\
winter & $32.8 \pm 3.1$ & $0.00 \pm 0.43$ & 0.00 \\
\hline
\end{tabular}

that the effect of changing baseline $\mathrm{O}_{3}$ was not statistically discernable for surface sites located in high precursor emission areas, since regional-scale influences were much more important. This work again emphasizes the need to carefully examine the suitability of a given data set for analysis of baseline $\mathrm{O}_{3}$ changes.

Ozone changes at sites downwind of North America, a continent with decreasing precursor emissions, may provide a useful comparison to the Japanese sites downwind of Asia. Bermuda (approximately $1000 \mathrm{~km}$ southeast of Cape Hatteras, North Carolina, US) and Sable Island Nova Scotia, Canada (approximately $900 \mathrm{~km}$ east and $175 \mathrm{~km}$ north of Boston, Massachusetts, US) are two sites downwind of North America where $\mathrm{O}_{3}$ measurements have been made since about 1990. However, neither of these data sets is ideal in that each has an extended gap in the late 1990s and early 2000s, and the measurements at Sable Island were particularly sporadic early in the record. Figures S18 and S19 show linear and quadratic regressions to those data sets, and Table 4 summarizes the parameters derived from the linear regressions. At Bermuda increasing $\mathrm{O}_{3}$ is noted in all seasons except autumn (although the increase is only marginally statistically significant in spring). Oltmans et al. (2006) also noted increasing $\mathrm{O}_{3}$ at Bermuda in spring and winter. It is noteworthy that $\mathrm{O}_{3}$ at Bermuda is increasing both during seasons of outflow of continental air (winter and spring) and during summer when the Bermuda-Azores high isolates Bermuda from direct North American influence. Sable Island presents a contrasting picture; the $\mathrm{O}_{3}$ change is not statistically significant in any season (due to the early sporadic measurements and the large interannual variation), but there is an indication of decreasing $\mathrm{O}_{3}$ in all seasons except winter. In summary, the $\mathrm{O}_{3}$ data records from two sites downwind of North 
America show only minimal influence from precursor emission changes on that continent, with Bermuda showing $\mathrm{O}_{3}$ increases from 1989-2010 generally similar to the baseline $\mathrm{O}_{3}$ changes at Mace Head (compare Tables 3 and 4). The $\mathrm{O}_{3}$ increases seen at Mt. Happo downwind of Asia are the largest within the data sets examined in this work, which supports the suggestion that increases in eastern $\mathrm{Asian} \mathrm{O}_{3}$ precursor emissions are at least partially responsible for the rapid $\mathrm{O}_{3}$ increases observed directly downwind of that continent.

\subsection{Changes of $\mathrm{O}_{3}$ seasonal cycles}

The seasonal differences in the long-term $\mathrm{O}_{3}$ changes that have occurred at northern mid-latitudes necessarily imply that the seasonal cycle of $\mathrm{O}_{3}$ has also changed over the time span of the data records. For example (see Fig. 2) in the 1970s at Hohenpeissenberg there was a summer maximum, a winter minimum and intermediate concentrations in spring and autumn. Presently, spring and summer have nearly equivalent seasonal averages that are both higher than autumn and winter, which are also nearly equivalent. Similar behavior is apparent at Arosa (Fig. S4), Zugspitze (Fig. S5), Jungfraujoch (Fig. S6), and even Arkona-Zingst (Fig. S1) in Europe, and Lassen NP (Fig. 4) in North America. A subsequent paper will explore these seasonal cycle changes more systematically and in more detail.

\section{Conclusions}

We have analyzed available $\mathrm{O}_{3}$ measurement records to quantify the changes in baseline tropospheric $\mathrm{O}_{3}$ concentrations that have occurred at northern mid-latitudes over the past six decades, the maximum time period covered by well-characterized measurements. The data sets were selected based upon (1) the quality and length of the measurement record, (2) measurements representative of baseline $\mathrm{O}_{3}$ concentrations, and (3) at least some coverage of all three northern mid-latitude continents. The primary analysis considered eleven total data sets: six European, three North American and two Asian; some additional analysis considered data from two sites downwind of North America. The earliest continuous measurements were begun in 1956, and a few other isolated measurements from the 1930s and 1950s are included.

A consistent picture emerges from these analyses. In general, the average $\mathrm{O}_{3}$ change has been positive at all sites in all seasons (Fig. 7a) when the full time periods of the data records are considered. Both the magnitudes of the $\mathrm{O}_{3}$ increases, as well as the absolute magnitude of the measured $\mathrm{O}_{3}$ concentrations (Fig. 6), generally increase with altitude. Thus, expressing the average $\mathrm{O}_{3}$ change as a percentage of the magnitude of the $\mathrm{O}_{3}$ concentration in the reference year 2000 reduces the variability of the $\mathrm{O}_{3}$ increases among the sites. A summary of the European and North American results can be simply stated: at least before 2000 , the average increase of $\mathrm{O}_{3}$ at each site was approximately the same at $1 \% \mathrm{yr}^{-1}$ relative to the respective $2000 \mathrm{yr}$ intercepts in each season. There is little if any evidence for statistically significant differences in average rates of increase among the nine European and North American sites. There are small significant seasonal differences, with average increases of $1.08 \pm 0.09,0.89 \pm 0.10,0.85 \pm 0.11$ and $1.21 \pm 0.12 \% \mathrm{yr}^{-1}$ in spring, summer, autumn and winter, respectively. To put the magnitude of these $\mathrm{O}_{3}$ changes in perspective, a constant change of $1 \% \mathrm{yr}^{-1}$ of the year 2000 intercept corresponds to a doubling from 1950 to 2000 . The very limited data available from the 1950s or before do indicate that the average $\mathrm{O}_{3}$ increases were sustained over the last half of the 20th century; however this rate of increase has more recently slowed at European sites, and less definitively at North American and Japanese sites. The data records analyzed began in widely varying years, but nevertheless give similar average $\mathrm{O}_{3}$ annual increases; this similarity supports the hypothesis of a sustained, approximately constant rate of $\mathrm{O}_{3}$ increase over the last half of the 20th century at northern mid latitudes.

The baseline $\mathrm{O}_{3}$ concentration change that has occurred exhibits a high degree of zonal uniformity over longitude. This can be demonstrated by considering the error bars in Fig. $7 b$, which indicate the $95 \%$ confidence limits of the average seasonal rates of increase at the individual sites. If it were hypothetically assumed that the entire northern mid-latitude region had experienced a uniform $\mathrm{O}_{3}$ change at all sites, with differing interannual variability superimposed, then $95 \%$ of the confidence limits of relative trends from individual sites would be expected to overlap the average seasonal $\mathrm{O}_{3}$ changes indicated by the black plus symbols in Fig. 7b. In actuality, $82 \%$ of the European and North American (and $75 \%$ of the Japanese) confidence limits do include the average seasonal $\mathrm{O}_{3}$ changes derived from the nine European and North American data sets. This close correspondence between the actual and the hypothetical inter-site agreement indicates that there is a high degree of longitudinal uniformity in the average seasonal $\mathrm{O}_{3}$ increases that occurred over the last half of the 20th century at northern mid-latitudes.

The Mt. Happo Japanese site directly downwind of the Asian continent has generally experienced larger absolute springtime $\mathrm{O}_{3}$ increases than those seen over Europe and North America. Relatively rapid increases are also found in free tropospheric data over North America and in particular in air masses originating from Asia (Cooper et al., 2010). These larger increases are likely attributable to the rapid increase in $\mathrm{O}_{3}$ precursor emissions that have occurred in East Asia. Sites directly downwind of North America within the MBL of the North Atlantic do not show such behavior, although the data are limited. Bermuda exhibits increases similar to Mace Head and West Coast North American MBL 
sites, while Sable Island shows some indication of decreasing $\mathrm{O}_{3}$.

Even though we have presented evidence for a sustained, approximately constant rate of $\mathrm{O}_{3}$ increase before the year 2000 over Europe and North America, we have also presented evidence that the rate of that $\mathrm{O}_{3}$ increase has slowed, particularly over western and central Europe and less definitively over North America and Japan. This slowing in the rate of increase has advanced to the point that seasonal average $\mathrm{O}_{3}$ over Europe has recently begun decreasing at some sites in some seasons, particularly summer. The linear analysis (based on Eq. 1) finds approximately the same average relative rate of $\mathrm{O}_{3}$ increase before 2000 at (nearly) all sites. The analysis assuming quadratic behavior (based on Eq. 2) derives a constantly decreasing rate of growth of $\mathrm{O}_{3}$, particularly over Europe. These somewhat contradictory conclusions reflect the statistical uncertainty that remains in choosing the mathematical model (Eq. 1 versus Eq. 2), in deriving the parameters from the mathematical models, as well as the time periods considered. The linear analysis provides the best estimate of the average annual increase in $\mathrm{O}_{3}$ over each data record, and Fig. 7b indicates that these estimates of relative $\mathrm{O}_{3}$ changes are remarkably consistent among all sites, regardless of length of data record, location or altitude. The second analysis provides the best estimate for the average annual rate of change in $\mathrm{O}_{3}$ growth rate over each data record; Fig. 8 shows that these estimates indicate generally slowing $\mathrm{O}_{3}$ growth rate throughout northern midlatitudes. It must be clearly noted that neither analysis implies that $\mathrm{O}_{3}$ at any site necessarily varied in either a linear (Eq. 1) or a quadratic (Eq. 2) manner, and certainly does not imply how $\mathrm{O}_{3}$ will change in the future. The derived parameters with their confidence limits do provide a convenient means to summarize long-term $\mathrm{O}_{3}$ changes at northern mid-latitudes.

This paper has presented a summary of long-term changes in lower tropospheric baseline $\mathrm{O}_{3}$ concentrations at northern mid-latitudes with the goal of providing benchmarks to which retrospective model calculations of the global $\mathrm{O}_{3}$ distribution can be compared. Satisfactory completion of these measurement-model comparisons is a necessary step in our efforts to fully understand the global $\mathrm{O}_{3}$ budget. Such comparisons should include the average long-term $\mathrm{O}_{3}$ increase in each season over the last half of the 20th century, and the more recent slowing of that increase, at least over the interior of the European continent.

\section{Supplementary material related to this article is available online at: http://www.atmos-chem-phys.net/12/ 11485/2012/acp-12-11485-2012-supplement.pdf.}

Acknowledgements. The authors are grateful to the Umweltamt of Graubünden and J. Thudium for providing the Arosa data sets, to the German Umweltbundesamt for providing recent data from Zingst, and to P. G. Simmonds and T. G Spain for providing the Mace Head data, to A. J. Manning for sorting the Mace Head data into baseline and non-baseline observations, to NOAA Earth System Research Laboratory, Global Monitoring Division for providing data from Trinidad Head and Bermuda, to US National Park Service 2002 for providing Lassen NP data, to Nova Scotia Environment, Air Quality and Resource Management Branch for providing Sable Is. data, and to Acid Deposition Monitoring Network in East Asia (EANET) for providing the Mt. Happo and Japanese MBL data. The authors also gratefully acknowledge the strong support of the MOZAIC program by the European Communities, EADS, Airbus and the airlines (Lufthansa, Austrian, Air France) who have carried the MOZAIC equipment free of charge since 1994. D. Parrish acknowledges support from NOAA's Health of the Atmosphere and Atmospheric Chemistry and Climate Programs. K. S. Law acknowledges support from the European Union Framework 7 (FP7) IP project PEGASOS (FP7-ENV2010/265148). H. Tanimoto acknowledges support from the Global Environment Research Fund of the Ministry of the Environment, Japan (S-7-1).

Edited by: R. Ebinghaus

\section{References}

ATMOFAST: Atmosphärischer Ferntransport und seine Auswirkungen auf die Spurengaskonzentrationen in der freien Troposphäre über Mitteleuropa (Atmospheric Longrange Transport and its Impact on the Trace-gas Composition of the Free Troposphere over Central Europe), Project Final Report: Trickl, T., Co-ordinator, Kerschgens, M., Stohl, A., and Trickl, T., subproject co-ordinators, funded by: the German Ministry of Education and Research within the programme "Atmosphärenforschung 2000", 130 pp., available at: http://www.trickl.de/ATMOFAST.htm, 2005.

Ayers, G. P., Penkett, S. A., Gillet, R. W., Bandy, B., Galbally, I. E., Meyer, C. P., Elsworth, C. M., Bentley, S. T., and Forgan, B. W.: Evidence for photochemical control of ozone concentrations in unpolluted marine air, Nature, 360, 446-449, 1992.

Brönnimann, S., Buchmann, B., and Wanner, H.: Trends in nearsurface ozone concentrations in Switzerland, Atmos. Environ., 36, 2841-2852, 2002.

Chameides, W. L. and Walker, J. C. G.: A photochemical theory of tropospheric ozone, J. Geophys. Res., 78, 8751-8760, 1973.

Chameides, W. L. and Walker, J. C. G.: A time-dependent model for ozone near the ground, J. Geophys. Res., 81, 413-420, 1976.

Chan, E. and Vet, R. J.: Baseline levels and trends of ground level ozone in Canada and the United States, Atmos. Chem. Phys., 10, 8629-8647, doi:10.5194/acp-10-8629-2010, 2010.

Chevalier, A., Gheusi, F., Delmas, R., Ordóñez, C., Sarrat, C., Zbinden, R., Thouret, V., Athier, G., and Cousin, J.-M.: Influence of altitude on ozone levels and variability in the lower troposphere: a ground-based study for western Europe over the period 2001-2004, Atmos. Chem. Phys., 7, 4311-4326, doi:10.5194/acp-7-4311-2007, 2007. 
Collins, W. J., Derwent, R. G., Garnier, B., Johnson, C. E., Sanderson, M. G., and Stevenson, D. S.: Effect of stratosphere- troposphere exchange on the future tropospheric ozone trend, J. Geophys. Res., 108, 8528, doi:10.1029/2002JD002617, 2003.

Cooper, O. R., Parrish, D. D., Stohl, A. Trainer, M., Nédélec, P., Thouret, V., Cammas, J. P., Oltmans, S. J., Johnson, B. J., Tarasick, D., Leblanc, T., McDermid, I. S., Jaffe, D., Gao, R., Stith, J., Ryerson T., Aikin, K., Campos, T., Weinheimer, A., and Avery, M. A.: Increasing springtime ozone mixing ratios in the free troposphere over western North America, Nature, 463, 344-348, doi:10.1038/nature08708, 2010.

Cox, R. A., Eggleton, A. E. J., Derwent, R. G., Lovelock, J. E., and Pack, D. H.: Long range transport of photochemical ozone in north-western Europe, Nature, 255, 118-121, 1975.

Crutzen, P. J.: A discussion of the chemistry of some minor constituents in the stratosphere and troposphere, Pure Appl. Geophys., 106-108, 1385-1399, 1973.

Crutzen, P. J.: Tropospheric ozone: an overview, in: Tropospheric Ozone, edited by: Isaksen, I. S. A. and Reidel, D., Dordrecht, 1988.

Cui, J., Pandey Deolal, S., Sprenger, M., Henne, S., Staehelin, J., Steinbacher, M., and Nédélec, P.: Free tropospheric ozone changes over Europe as observed at Jungfraujoch (1990-2008): An analysis based on backward trajectories, J. Geophys. Res., 116, D10304, doi:10.1029/2010JD015154, 2011.

Derwent, R. G., Simmonds, P. G., Manning, A. J., and Spain, T. G.: Trends over a 20-year period from 1987 to 2007 in surface ozone at the atmospheric research station, Mace Head, Ireland, Atmos. Environ., 41, 9091-9098, 2007.

Feister, U. and Warmbt, W. G.: Long-term measurements of surface ozone in the German Democratic Republic, J. Atmos. Chem., 5, 1-21, 1987.

Forster, C., Cooper, O., Stohl, A., Eckhardt, S., James, P., Dunlea, E., Nicks Jr., D. K., Holloway, J. S., Hübler, G., Parrish, D. D., Ryerson, T. B., and Trainer, M.: Lagrangian transport model forecasts and a transport climatology for the Intercontinental Transport and Chemical Transformation 2002 (ITCT 2K2) measurement campaign, J. Geophys. Res., 109, D07S92, doi:10.1029/2003JD003589, 2004.

Fusco, A. C. and Logan, J. A.: Analysis of 1970-1995 trends in tropospheric ozone at northern hemisphere midlatitudes with the GEOS-CHEM model, J. Geophys. Res., 108, 4449, doi:10.1029/2002JD002742, 2003.

Galbally, I. E. and Roy, C. R.: Destruction of ozone at the earth's surface, Q. J. Roy. Met. Soc., 106, 599-620, 1980.

Gilge, S., Plass-Duelmer, C., Fricke, W., Kaiser, A., Ries, L., Buchmann, B., and Steinbacher, M.: Ozone, carbon monoxide and nitrogen oxides time series at four alpine GAW mountain stations in central Europe, Atmos. Chem. Phys., 10, 12295-12316, doi:10.5194/acp-10-12295-2010, 2010.

Granier, C., Bessagnet, B., Bond, T., D’Angiola, A., Gon, H.D.v.d., Frost, G.J., Heil, A., Kaiser, J. W., Kinne, S., Klimont, Z., Kloster, S., Lamarque, J.-F., Liousse, C., Masui, T., Meleux, F., Mieville, A., Ohara, T., Raut, J.-C., Riahi, K., Schultz, M. G., Smith, S. J., Thomson, A., Aardenne, J.v., Werf, G. R. v. d., and Vuuren, D. P. v.: Evolution of anthropogenic and biomass burning emissions of air pollutants at global and regional scales during the 1980-2010 period, Clim. Change, 109, 163-190, doi:10.1007/s10584-011-0154-1, 2011.
Guerova, G., Bey, I., Atti'e, J.-L., Martin, R. V., Cui, J., and Sprenger, M.: Impact of transatlantic transport episodes on summertime ozone in Europe, Atmos. Chem. Phys., 6, 2057-2072, doi:10.5194/acp-6-2057-2006, 2006.

Hess, P. G. and Zbinden, R.: Stratospheric impact on tropospheric ozone variability and trends: 1990-2009, Atmos. Chem. Phys. Discuss., 11, 22719-22770, doi:10.5194/acpd-11-22719-2011, 2011.

Horowitz, L. W.: Past, present, and future concentrations of tropospheric ozone and aerosols: Methodology, ozone evaluation, and sensitivity to aerosol wet removal, J. Geophys. Res., 111, D22211, doi:10.1029/2005JD006937, 2006.

HTAP: Hemispheric Transport of Air Pollution 2010, Part A: Ozone and Particulate Matter, Air Pollution Studies No. 17, edited by: Dentener, F., Keating, T., and Akimoto, H., United Nations, New York and Geneva, 2010.

IPCC: Summary for Policymakers, in: Climate Change 2007: The Physical Science Basis, Contribution of Working Group I to the Fourth Assessment Report of the Intergovernmental Panel on Climate Change, edited by: Solomon, S., Qin, D., Manning, M., Chen, Z., Marquis, M., Averyt, K. B., Tignor, M., and Miller, H. L., Cambridge University Press, Cambridge, United Kingdom and New York, NY, USA, 2007.

Jaffe, D., Price, H., Parrish, D. D., Goldstein, A., and Harris, J.: Increasing background ozone during spring on the west coast of North America, Geophys. Res. Lett., 30, 1613, doi:10.1029/2003GL017024, 2003.

Jenkin, M. E.: Trends in ozone concentration distributions in the UK since 1990: Local, regional and global influences, Atmos. Environ., 42, 5434-5445, 2008.

Junge, C. E.: Air Chemistry and Radioactivity, 49-59, Academic Press, New York, 1963.

Kley, D., Volz, A., and Mülheims, F.: Ozone Measurements in Historic Perspective, in: Tropospheric Ozone - Regional and Global Scale Interactions, edited by: Isaksen, I. S. A., 63-72, D. Reidel Publishing Comp., Dordrecht, 1988.

Lamarque, J.-F., Kiehl, J. T., Brasseur, G. P., Butler, T., CameronSmith, P., Collins, W. D., Collins, W. J., Granier, C., Hauglustaine, D., Hess, P. G., Holland, E. A., Horowitz, L. , Lawrence, M. G., McKenna, D., Merilees, P., Prather, M. J., Rasch, P. J., Rotman, D., Shindell, D., and Thornton, P.: Assessing future nitrogen deposition and carbon cycle feedback using a multimodel approach: Analysis of nitrogen deposition, J. Geophys. Res., 110, D19303, doi:10.1029/2005JD005825, 2005.

Lamarque, J.-F., Bond, T. C., Eyring, V., Granier, C., Heil, A., Klimont, Z., Lee, D., Liousse, C., Mieville, A., Owen, B., Schultz, M. G., Shindell, D., Smith, S. J., Stehfest, E., Van Aardenne, J., Cooper, O. R., Kainuma, M., Mahowald, N., McConnell, J. R., Naik, V., Riahi, K., and van Vuuren, D. P.: Historical (1850-2000) gridded anthropogenic and biomass burning emissions of reactive gases and aerosols: methodology and application, Atmos. Chem. Phys., 10, 7017-7039, doi:10.5194/acp10-7017-2010, 2010.

Logan, J. A.: Trends in the vertical distribution of ozone: An analysis of ozonesonde data, J. Geophys. Res., 99, 25553-25585, 1994.

Logan, J. A.: Interactive comment on "Long-term changes in lower tropospheric baseline ozone concentrations at northern midlatitudes" by D. D. Parrish et al., Atmos. Chem. Phys. Discuss., 
12, C5000-C5000, 2012.

Logan, J. A., Megretskaia, I. A., Miller, A. J., Tia, G. C., Choi, D., Zhang, L., Stolarski, R. S., Labow, G. J.,Hollandsworth, S. M., Bodeker, G. E., Claude, H., DeMuer, D., Kerr, J. B., Tarasick, D. W., Oltmans, S. J., Johnson, B., Schmidlin, F., Staehelin, J., Viatte, P., and Uchino, O.: Trends in the vertical distribution of ozone: A comparison of two analyses of ozonesonde data, J. Geophys. Res., 104, 26373-26399, 1999.

Logan, J. A., Staehelin, J., Megretskaia, I. A., Cammas, J.-P., Thouret, V., Claude, H., De Backer, H., Steinbacher, M., Scheel, H. E., Stübi, R., Fröhlich, M., and Derwent, R.: Changes in ozone over Europe: analysis of ozone measurements from sondes, regular aircraft (MOZAIC) and alpine surface sites, J. Geophys. Res., 117, D09301, doi:10.1029/2011JD016952, 2012.

McDonald-Buller, E. C., Allen, D. T., Brown, N., Jacob, D. J., Jaffe, D. , Kolb, C. E., Lefohn, A. S., Oltmans, S., Parrish, D. D., Yarwood, G., and Zhang, L.: Establishing Policy Relevant Background (PRB) Ozone Concentrations in the United States, Environ. Sci. Technol., 45, 9484-9497, doi:10.1021/es2022818, 2011.

Naja, M., Akimoto, H., and Staehelin, J.: Ozone background and photochemically aged air over central Europe: Analysis of longterm ozone sonde data from Hohenpeissenberg and Payerne, J. Geophys. Res., 108, 4063, doi:10.1029/2002JD002477, 2003.

Ohara, T., Akimoto, H., Kurokawa, J., Horii, N., Yamaji, K., Yan, X., and Hayasaka, T.: An Asian emission inventory of anthropogenic emission sources for the period 1980-2020, Atmos. Chem. Phys., 7, 4419-4444, doi:10.5194/acp-7-4419-2007, 2007.

Oltmans, S., Lefohn, A. S., Harris, J. M., Galbally, I., Scheel, H. E., Bodeker, G., Brunke, E., Claude, H., Tarasick, D., Johnson, B. J., Simmonds, P., Shadwick, D., Anlauf, K., Hayden, K., Schmidlin, F., Fujimoto, T., Akagi, K., Meyer, C., Nichol, S., Davies, J., Redondas, A., and Cuevaso, E.: Long-term changes in tropospheric ozone, Atmos. Environ., 40, 3156-3173, 2006.

Ordóñez, C., Brunner, D., Staehelin, J., Hadjinicolaou, P., Pyle, J. A., Jonas, M., Wernli, H., and Prévôt, A. S. H.: Strong influence of lowermost stratospheric ozone on lower tropospheric background ozone changes over Europe, Geophys. Res. Lett., 34, L07805, doi:10.1029/2006GL029113, 2007.

Parrish, D. D., Trainer, M., Holloway, J. S., Yee, J. E., Warshawsky, M. S., Fehsenfeld, F. C., Forbes, G. L., and Moody, J. L.,: Relationships between ozone and carbon monoxide at surface sites in the North Atlantic region, J. Geophys. Res., 103, 13357-13376, 1998.

Parrish, D. D., Millet, D. B., and Goldstein, A. H.: Increasing ozone in marine boundary layer inflow at the west coasts of North America and Europe, Atmos. Chem. Phys., 9, 1303-1323, doi:10.5194/acp-9-1303-2009, 2009.

Parrish, D. D., Law, K. S., Staehelin, J., Derwent, R., Cooper, O. R., Tanimoto, H., Volz-Thomas, A., Gilge, S., Scheel, H.-E., Steinbacher, M., and Chan, E.: Interactive comment on "Longterm changes in lower tropospheric baseline ozone concentrations at northern mid-latitudes", Atmos. Chem. Phys. Discuss., 12, C6925-C6950, 2012.
Pausata, F. S. R., Pozzoli, L., Vignati, E., and Dentener, F. J.: North Atlantic Oscillation and tropospheric ozone variability in Europe: model analysis and measurements intercomparison, Atmos. Chem. Phys. Discuss., 12, 3131-3167, doi:10.5194/acpd12-3131-2012, 2012.

Penkett, S. A. and Brice, K. A.: The spring maximun in photooxidants in the Northern Hemisphere troposphere, Nature, 319, 655-657, 1986.

Royal Society: Ground-level ozone in the 21st century: future trends, impacts and policy implications, RS Policy document 15/08, The Royal Society, London, 2008.

Schnadt Poberaj, C., Staehelin, J., Brunner, D., Thouret, V., De Backer, H., and Stübi, R.: Long-term changes in UT/LS ozone between the late 1970s and the 1990s deduced from the GASP and MOZAIC aircraft programs and from ozonesondes, Atmos. Chem. Phys., 9, 5343-5369, doi:10.5194/acp-9-5343-2009, 2009.

Staehelin, J., Thudium, J., Buehler, R., Volz-Thomas, A., and Graber, W.: Trends in surface ozone concentrations at Arosa (Switzerland), Atmos. Environ., 28, 75-87, 1994.

Tanimoto, H.: Increase in springtime tropospheric ozone at a mountainous site in Japan for the period 1998-2006, Atmos. Environ., 43, 1358-1363, 2009.

Tanimoto, H., Ohara, T., and Uno, I.: Asian anthropogenic emissions and decadal trends in springtime tropospheric ozone over Japan: 1998-2007, Geophys. Res. Lett., 36, L23802, doi:10.1029/2009GL041382, 2009.

Tressol, M., Ordonez, C., Zbinden, R., Brioude, J., Thouret, V., Mari, C., Nedelec, P., Cammas, J.-P., Smit, H., Patz, H.-W., and Volz-Thomas, A.: Air pollution during the 2003 European heat wave as seen by MOZAIC airliners, Atmos. Chem. Phys., 8, 2133-2150, doi:10.5194/acp-8-2133-2008, 2008.

Vingarzan, R.: A review of surface ozone background levels and trends, Atmos. Environ., 38, 3431-3442, 2004.

Volz, A. and Kley, D.: Evaluation of the Montsouris series of ozone measurements made in the 19th-century, Nature, 332, 240-242, 1988.

Wild, O., Law, K. S., McKenna, D. S., Bandy, B. J., Penkett, S. A., and Pyle, J. A.: Photochemical trajectory modeling studies of the North Atlantic region during August 1993, J. Geophys. Res., 101, 29269-29288, doi:10.1029/96JD00837, 1996.

Zhang, L., Jacob, D. J., Downey, N. V., Wood, D. A., Blewitt, D., Carouge, C. C., van Donkelaar, A., Dylan, Jones, D. B. A., Murray, L. T., and Wang, Y.: Improved estimate of the policy-relevant background ozone in the United States using the GEOS-Chem global model with $1 / 2^{\circ} \times 2 / 3^{\circ}$ horizontal resolution over North America, Atmos. Environ., 45, 6769-6776, 2011. 